\title{
ANISORROPIA: the adjoint of the aerosol thermodynamic model ISORROPIA
}

\author{
S. L. Capps ${ }^{1}$, D. K. Henze ${ }^{2}$, A. Hakami ${ }^{3}$, A. G. Russell ${ }^{4}$, and A. Nenes ${ }^{1,5}$ \\ ${ }^{1}$ School of Chemical and Biomolecular Engineering, Georgia Institute of Technology, Atlanta, GA, USA \\ ${ }^{2}$ Deparment of Mechanical Engineering, University of Colorado, Boulder, CO, USA \\ ${ }^{3}$ Department of Civil and Environmental Engineering, Carleton University, Ottawa, ON, Canada \\ ${ }^{4}$ School of Civil and Environmental Engineering, Georgia Institute of Technology, Atlanta, GA, USA \\ ${ }^{5}$ School of Earth and Atmospheric Sciences, Georgia Institute of Technology, Atlanta, GA, USA
}

Correspondence to: A. Nenes (athanasios.nenes@gatech.edu)

Received: 2 August 2011 - Published in Atmos. Chem. Phys. Discuss.: 19 August 2011

Revised: 23 December 2011 - Accepted: 23 December 2011 - Published: 10 January 2012

\begin{abstract}
We present the development of ANISORROPIA, the discrete adjoint of the ISORROPIA thermodynamic equilibrium model that treats the $\mathrm{Na}^{+}-\mathrm{SO}_{4}^{2-}-\mathrm{HSO}_{4}^{-}-\mathrm{NH}_{4}^{+}-\mathrm{NO}_{3}^{-}$$\mathrm{Cl}^{-}-\mathrm{H}_{2} \mathrm{O}$ aerosol system, and we demonstrate its sensitivity analysis capabilities. ANISORROPIA calculates sensitivities of an inorganic species in aerosol or gas phase with respect to the total concentrations of each species present with less than a two-fold increase in computational time over the concentration calculations. Due to the highly nonlinear and discontinuous solution surface of ISORROPIA, evaluation of the adjoint required a new, complex-variable version of the model, which determines first-order sensitivities with machine precision and avoids cancellation errors arising from finite difference calculations. The adjoint is verified over an atmospherically relevant range of concentrations, temperature, and relative humidity. We apply ANISORROPIA to recent field campaign results from Atlanta, GA, USA, and Mexico City, Mexico, to characterize the inorganic aerosol sensitivities of these distinct urban air masses. The variability in the relationship between fine mode inorganic aerosol mass and precursor concentrations shown has important implications for air quality and climate.
\end{abstract}

\section{Introduction}

Atmospheric chemical transport models (CTMs) are used for many purposes including assessment of radiative climate forcing of aerosol (Forster et al., 2007) and evaluation of the effectiveness of emissions control strategies designed to reduce exposure of humans to particulates (US EPA, 2004). The accuracy of these estimates is limited by model representations of chemical and physical processes as well as model parameters (e.g., emissions rates). Attributing climate forcing and air quality degradation to sources is challenging with sensitivity analysis techniques based on standard model output (Shindell et al., 2008, 2009). Inorganic species, primarily sulfate $\left(\mathrm{SO}_{4(p)}^{2-} / \mathrm{HSO}_{4(p)}^{-}\right)$, ammonium $\left(\mathrm{NH}_{4(p)}^{+}\right)$, nitrate $\left(\mathrm{NO}_{3(p)}^{-}\right)$, sodium $\left(\mathrm{Na}_{(p)}^{+}\right)$, and chloride $\left(\mathrm{Cl}_{(p)}^{-}\right)$, constitute a significant fraction of dry aerosol mass (Heintzenberg, 1989). The nonlinear formation of inorganic aerosol from gas phase precursors is reasonably well-characterized (Nenes et al., 1999). However, the precision of emissions estimates of aerosol precursors varies widely depending upon source type and region of the world (Klimont and Streets, 2007). Adjoint-based sensitivity analysis enhances the ability to assess the relative influence of aerosol precursor emissions on air quality metrics and aerosol radiative forcing of climate as well as providing a means of refining emissions estimates with observations in an inverse modeling framework. 
The highly variable sensitivity of fine mode ammoniumsulfate-nitrate aerosol to precursor concentrations (Ansari and Pandis, 1998; West et al., 1999) makes the robust assessment of emissions influences challenging. West et al. (1998) demonstrated climatic implications of this variability by quantifying the marginal direct radiative forcing of inorganic aerosols. Vayenas et al. (2005) explored the relationship of $\mathrm{SO}_{2(\mathrm{~g})}$ and $\mathrm{NO}_{\mathrm{x}(\mathrm{g})}$ emissions to $\mathrm{SO}_{4}^{2-}-\mathrm{HSO}_{4}^{-}-\mathrm{NH}_{4}^{+}-$ $\mathrm{NO}_{3}^{-}$aerosol concentrations in an observationally driven $\mathrm{Eu}-$ lerian model over the eastern United States, finding significant variation in effectiveness of controls because of the nonlinear transformation of gaseous precursors to aerosol. Pinder et al. (2007) demonstrated the efficiency of reducing $\mathrm{NH}_{3(\mathrm{~g})}$ emissions relative to $\mathrm{SO}_{2(\mathrm{~g})}$ and $\mathrm{NO}_{\mathrm{x}(\mathrm{g})}$ for air quality objectives with the PM-CAMx CTM (Gaydos et al., 2007) by perturbing emissions of $\mathrm{NH}_{3(\mathrm{~g})}, \mathrm{SO}_{2(\mathrm{~g})}$, and $\mathrm{NO}_{\mathrm{x}(\mathrm{g})}$ by fifty percent. Although the finite difference approach employed in this and other studies, sometimes termed "emissions toggling", is the most straightforward sensitivity analysis technique, it is limited in that computational requirements scale with the number of emissions investigated; perturbations to the atmospheric conditions from the changed emissions obscure nonlinear effects; and cancellation errors limit the accuracy of this method. The decoupled direct method (DDM), an implementation of a tangent linear model (TLM), can be used to understand the impact of selected emissions on the field of air quality or health metrics without changing emissions parameters (Dunker, 1984; Napelenok et al., 2006; Koo et al., 2007); second-order source-oriented sensitivities of inorganic aerosol can now quantify nonlinear contributions to sensitivity (Zhang et al., 2011). Establishing the source-receptor relationship of inorganic aerosol by these forward sensitivity analysis methods (i.e., emissions toggling, DDM/TLM) reveals emissions impacts of particular sources on the field of concentrations. Source-oriented sensitivity analysis is less helpful for evaluating relative impacts of emissions, and inverse modeling with source-oriented sensitivities is limited in application due to computational cost, which scales with model parameters assessed (MendozaDominguez and Russell, 2001).

The adjoint method complements forward sensitivity approaches by efficiently elucidating the relationship of model output (e.g., specified concentrations, air quality metrics) to the field of model parameters, or input, (e.g., emissions, initial conditions) without perturbing model inputs. Computational requirements for calculation of these receptor-oriented sensitivities are insensitive to the number of model parameters investigated. Thus, adjoints can efficiently calculate sensitivities of air quality or climate-forcing metrics with respect to a vast number of parameters (e.g., 10 ${ }^{5}$ ) in accordance with model chemistry and physics. This receptor-oriented approach facilitates optimization of model parameters in accordance with observations in a 4-dimensional variational (4D-Var) data assimilation framework.
Meteorologists have exploited adjoints for optimization of initial conditions and other parameters for decades (Sasaki, 1958; Marchuk, 1974; Lamb et al., 1975; Talagrand, 1981; Talagrand and Courtier, 1987). CTM adjoints have been used to explore relationships of concentrations of gaseous species and emissions (Menut et al., 2000; Vukićević and Hess, 2000; Sandu et al., 2005a; Hakami et al., 2006; Martien and Harley, 2006) and to refine estimates of trace gases in the atmosphere (Fisher and Lary, 1995; Elbern et al., 1997; Kaminski et al., 1999; Elbern et al., 2000; Müller and Stavrakou, 2005; Zhang et al., 2008; Kopacz et al., 2009). Gas phase 4D-Var data assimilation has been employed to improve agreement of model predictions with in situ observations (e.g., Chai et al., 2006) or remote sensing (e.g., Resler et al., 2010). Kukkonen et al. (2012) anticipate the utility of 4D-Var data assimilation of trace gas observations within a coupled meteorological-chemical forecasting model framework for real-time improvement of air quality forecasting.

Application of adjoint methods to study aerosols is relatively new, likely due, in part, to the difficulty of developing adjoints of aerosol models as well as recent attention to refining aerosol concentration estimates in CTMs. Henze et al. (2004) and Sandu et al. (2005b) demonstrated the feasibility of developing an adjoint for the coagulation and growth of a multi-component aerosol population in a 0-D model. Hakami et al. (2005) first optimized initial and boundary conditions as well as emissions rates of non-reactive black carbon (BC) aerosol using an adjoint of the STEM-2k1 model (Carmichael et al., 2003; Sandu et al., 2005a) to assimilate in situ observations from ACE-Asia (Huebert et al., 2003; Seinfeld et al., 2004). The adjoint of GOCART, a global aerosol transport model, demonstrated the utility of satellitebased aerosol observations for constraining highly uncertain aerosol emissions parameters (Dubovik et al., 2008). The distribution and long-range transport of Asian dust have been investigated with a 4D-Var data assimilation version of a regional dust transport model (RC4) with both in situ and remotely sensed observations (Yumimoto et al., 2007, 2008; Uno et al., 2008; Sekiyama et al., 2010). The direct and albedo forcings of black carbon deposited on the Tibetan Plateau were characterized by Kopacz et al. (2011) with the adjoint of GEOS-Chem. Henze et al. (2007) first included secondary formation of inorganic aerosol in the adjoint of GEOS-Chem using MARS-A aerosol thermodynamic model of the $\mathrm{SO}_{4}^{2-}-\mathrm{HSO}_{4}^{-}-\mathrm{NH}_{4}^{+}-\mathrm{NO}_{3}^{-}-\mathrm{H}_{2} \mathrm{O}$ aerosol system (Binkowski and Roselle, 2003). With this framework, Henze et al. (2009) conducted inverse modeling of inorganic fine mode aerosol observations from the IMPROVE network (Malm et al., 1994) to identify influences of aerosol precursor emissions on US air quality.

Many regional and global CTMs employ the ISORROPIA/ISORROPIA-II (Nenes et al., 1998, 1999; Fountoukis and Nenes, 2007) aerosol thermodynamic equilibrium model. ISORROPIA treats the $\mathrm{Na}^{+}-\mathrm{SO}_{4}^{2-}-\mathrm{HSO}_{4}^{-}$ 
$\mathrm{NH}_{4}^{+}-\mathrm{NO}_{3}^{-}-\mathrm{Cl}^{-}-\mathrm{H}_{2} \mathrm{O}$ aerosol system by efficiently and accurately calculating the partitioning of precursor gases and water vapor to aerosol at a specified temperature and relative humidity (RH). ISORROPIA simulates secondary inorganic aerosol formation in CHIMERE (Schmidt et al., 2001; Bessagnet et al., 2004), Community Multiscale Air Quality model (CMAQ) (Byun and Schere, 2006), Comprehensive Air Quality Model with Extensions (CAMx) (ENVIRON, 1997, 2010), COSMO-ART (Vogel et al., 2009), GEOSChem (http://geos-chem.org/) (Bey et al., 2001; Pye et al., 2009), LOng Term Ozone Simulation-EURopean Operational Smog model (LOTOS-EUROS) (Schaap et al., 2008), and the Sulfur Transport dEposition Model (STEM-2k1) (Carmichael et al., 2003). Although ISORROPIA is capable of treating the entire water uptake curve, CTMs neglect the formation of solid phases and assume aerosols exist in a metastable state.

Receptor-oriented sensitivity analysis and inverse modeling have been limited to gaseous species or inert aerosol for CTMs that employ ISORROPIA due to the absence of its adjoint, which this work addresses. We present the development of ANISORROPIA (AdjoiNt of ISORROPIA) (Sect. 2), demonstrate its accuracy at atmospherically relevant conditions (Sect. 3), and apply it to examine observed aerosol mixture responses (Sect. 4). Finally, the utility of ANISORROPIA within adjoints of CTMs is anticipated (Sect. 5).

\section{Methods}

The adjoint of a CTM determines sensitivities of a metric of specified output parameters (e.g., air quality attainment metric) with respect to a wide array of input parameters (i.e., emissions rates). Conceptually, an infinitesimal variation in a single output variable evolves backwards through modeled processes, indicating the corresponding perturbations of input parameters required to effect the infinitesimal change in output. Realizing this capability in a CTM with an online simulation of aerosol involves considerable methodological and coding development. Outlined in the following sections are the role of ISORROPIA in CTMs (Sect. 2.1), the framework for adjoint-based sensitivity analysis (Sect. 2.2), and the specific tactics employed to develop ANISORROPIA (Sect. 2.3).

\subsection{The ISORROPIA model}

Key components of fine mode aerosol are water, inorganic salts, crustal minerals, organics, and trace metals (Seinfeld and Pandis, 2006). Inorganic species constitute about 25$50 \%$ of the dry mass of a typical continental particle, the most abundant being sulfate $\left(\mathrm{SO}_{4(p)}^{2-} / \mathrm{HSO}_{4(p)}^{-}\right)$, ammonium $\left(\mathrm{NH}_{4(p)}^{+}\right)$, and nitrate $\left(\mathrm{NO}_{3(p)}^{-}\right)$. Sodium $\left(\mathrm{Na}_{(p)}^{+}\right)$and chloride $\left(\mathrm{Cl}_{(p)}^{-}\right)$ions contribute significantly in environments with marine character or near dry lake beds (Heintzenberg, 1989). CTMs often treat fine mode particles as existing in thermodynamic equilibrium with the surrounding gases based on the short equilibration time scales for these particles (Ansari and Pandis, 1999b; Dassios and Pandis, 1999; Fountoukis et al., 2009).

A number of thermodynamic models have been developed to model aerosol thermodynamic equilibrium with varying degrees of comprehensiveness, accuracy, and efficiency (e.g., AIM (Clegg et al., 1998); GFEMIN (Ansari and Pandis, 1999a); EQSAM3 (Metzger et al., 2006; Metzger and Lelieveld, 2007); EQUISOLV II (Jacobson et al., 1996; Jacobson, 1999); ISORROPIA and ISORROPIA II (Nenes et al., 1998, 1999; Fountoukis and Nenes, 2007); MARS-A (Saxena et al., 1986; Binkowski and Roselle, 2003); MESA (Zaveri et al., 2005); SCAPE2 (Kim et al., 1993a,b; Meng and Seinfeld, 1996); UHAERO (Amundson et al., 2006)).

Until now, the adjoint of one thermodynamic equilibrium model has been developed: RPMARES, an implementation of the MARS-A model for GEOS-Chem (Binkowski and Roselle, 2003; Park et al., 2004; Henze et al., 2007). RPMARES treats the ammonium-sulfate-nitrate aerosol system with temperature-independent activity coefficients based on the Pitzer model for binary coefficients. ISORROPIA treats two additional species, sodium and chloride, and includes temperature dependence when calculating activity coefficients by the Kusik-Meissner (K-M) method. K-M compares well with experimental results as does Pitzer, but, unlike Pitzer, also continues to produce physically reasonable results at higher ionic strengths (i.e., greater than 30 molar) (Harvie et al., 1984; Cohen et al., 1987; Kim et al., 1993b). In ISORROPIA, water uptake is calculated in accordance with AIM Model III (http://www.aim.env.uea.ac.uk/aim/aim. php) rather than older data sets (Binkowski and Roselle, 2003; Fountoukis and Nenes, 2007). Inclusion of additional species, increased accuracy compared to RPMARES, and widespread utilization of ISORROPIA in CTMs motivated development of ANISORROPIA.

ISORROPIA solves the aerosol-gas partitioning problem in two different modes: forward and reverse. Model input for the forward mode is the total amount of species present in the gas and aerosol; it outputs the gas phase and aerosol concentrations of each of the species. The reverse mode requires the concentration of species in the aerosol and calculates gas phase concentrations of species in equilibrium. The focus of the current work is the forward mode as it is more widely employed. The reverse mode is useful for aerosol dynamics codes with active mass transfer of aerosol species (e.g., Capaldo et al., 2000; Pilinis et al., 2000; Kelly et al., 2010).

ISORROPIA uses ten distinct algorithms to determine equilibrium based on the relative abundance of negatively and positively charged ionic species for the $\mathrm{NH}_{4}^{+}-\mathrm{SO}_{4}^{2-}$ $\mathrm{HSO}_{4}^{-}-\mathrm{NO}_{3}^{-}-\mathrm{Na}^{+}-\mathrm{Cl}^{-}-\mathrm{H}_{2} \mathrm{O}$ aerosol system. The sulfate ratio, $R_{S}=\frac{\left[\text { Total } \mathrm{NH}_{3}\right]+[\text { Total } \mathrm{Na}]}{\left[\mathrm{Total}_{2} \mathrm{SO}_{4}\right]}$, determines which solution 
branch is employed. For $R_{S} \geq 2$, the neutralized solution regime is accessed since sufficient ammonium and sodium are present to neutralize the aerosol sulfate. $R_{S}<2$ invokes one of the seven acidic solution algorithms. Discretization of the solution space reduces the computational complexity and increases efficiency of determining equilibrium of a multicomponent system; therefore, ANISORROPIA was designed to be congruent with the underlying model.

\subsection{Mathematical background}

Adjoint-based sensitivity analysis complements the direct decoupled method of sensitivity analysis more often employed in three-dimensional CTMs. Because of the relatively novel application of adjoint methods to CTMs and their internal models, the mathematical basis for the discrete adjoint of the forward mode of ISORROPIA is given. A comprehensive description of the mathematical framework for discrete and continuous adjoints of CTMs can be found in Sandu et al. (2005a).

Forward mode ISORROPIA partitions concentrations of inorganic species summed over solid, liquid, and gas phases into the appropriate concentration in each phase at thermodynamic equilibrium. ISORROPIA can be represented as a function, $F$, that propagates the total concentration, $c_{i}^{t}$, to the appropriate phase concentrations, $c_{i}^{p}$, for each species, $i$ (Eq. 1). The vectors $c^{p}$ and $c^{t}$ represent all species.

$c^{p}=F\left(c^{t}\right)$

A scalar response function, $\mathcal{J}$, of the model is given by

$\mathcal{J}\left(c^{t}\right)=g\left(c^{p}\right)$

The derivatives of the response function, $\mathcal{J}$, with respect to the total concentrations, $c^{t}$, are desired. A infinitesimal perturbation, $\delta c^{t}$, in $c^{t}$ propagates to $\delta c^{p}$ by the tangent linear model (Eq. 3).

$\delta c^{p}=F^{\prime} \circ \delta c^{t}$

An adjoint operator, denoted by $F^{*}$ here, corresponds to the tangent linear operator such that

$\lambda^{t}=F^{*} \circ \lambda^{p}+\phi$.

Thus, adjoint vectors, $\lambda^{p}$, corresponding to $c^{p}$, and a forcing function, $\phi$, are propagated to $\lambda^{t}$. Appropriate selection of the values of $\lambda^{p}$ and $\phi$ allow the desired result,

$\lambda_{i}^{t}=\frac{\partial\left[\mathcal{J}\left(c^{t}\right)\right]}{\partial c_{i}^{t}}=\frac{\partial\left[g\left(c^{p}\right)\right]}{\partial c_{i}^{t}}$

for each species, $i$. The discrete adjoint model, $F^{\prime *}$, which is ANISORROPIA, maintains the algorithmic structure of the original function, $F$ or ISORROPIA. ANISORROPIA can produce the derivatives of interest independently, as demonstrated in this work. It could also be integrated into the adjoint of a CTM to propagate adjoint vectors through the processes described by ISORROPIA.

\subsection{Development of ANISORROPIA}

Accumulation of adjoint sensitivities occurs through a set of calculations which parallel the original model. A model adjoint can be formed in one of two ways. If the governing equations are differentiated and then transformed into a numerical algorithm, the adjoint is termed a continuous adjoint; the algorithmic treatment of a continuous adjoint model may differ significantly from the original model. Conversely, a discrete adjoint is formed by the differentiation of the forward model in accordance with the original model algorithm. Automatic differentiation (AD) tools, which apply the chain rule of differential calculus line by line, can be efficiently employed as aids to discrete adjoint development (http://www.autodiff.org/); alternately, the discrete adjoint can be developed by manually processing the code line by line.

A discrete adjoint is developed to maintain consistency with ISORROPIA and to retain the efficiency of ISORROPIA, which largely arises from the discretization of the solution space. Branching and discontinuity (not unique to ISORROPIA, as theoretically any code containing "GO TO", "IF", "MAX/MIN", "ABS" and other similar functions introduce branching and discontinuities) do not prohibit the development of a discrete adjoint, because a continuous set of solutions and derivatives can be derived for each subdomain of the code. This is not the case for sensitivities evaluated with other methods (e.g., finite differences), as they can frequently involve function evaluations across solution regimes and thus provide fundamentally inaccurate values. ANISORROPIA has been developed for each of the ten solution regimes involved in the forward mode for the deliquesced $\mathrm{NH}_{4}^{+}-\mathrm{SO}_{4}^{2-}$ $\mathrm{HSO}_{4}^{-}-\mathrm{NO}_{3}^{-}-\mathrm{Na}^{+}-\mathrm{Cl}^{-}-\mathrm{H}_{2} \mathrm{O}$ aerosol system. The appropriate solution regime is accessed according to the relative abundance of total species present. An internal driver calls the appropriate adjoint routine based on the acidity of the aerosol, which is consistent with that executed by the forward model. ANISORROPIA does not checkpoint, or store to a file, the solution regime called during the forward execution of ISORROPIA because a simple arithmetic calculation from input to ANISORROPIA is sufficient to select the appropriate solution pathway.

Within each of the ten solution pathways, ISORROPIA remains sufficiently complex that writing the adjoint of this FORTRAN code by hand would be very challenging. The high degree of interdependence in addition to the length of the code $(\sim 10000$ lines) made employing an $\mathrm{AD}$ tool an attractive alternative. TAPENADE, an AD tool for FORTRAN and C programs (Hascoët and Pascual, 2004), was used to apply the chain rule of derivative calculus line by line such that differentials of dependent variables with respect to intermediate variables can accumulate (in accordance with an adjoint forcing vector) to produce the sensitivity of a dependent-variable with respect to independent variables (http://www.autodiff.org/). ISORROPIA originally 
calculated activity coefficients to single-precision; development of ANISORROPIA required conversion of all variables to double-precision to accumulate sensitivities through this aspect of the model accurately.

ANISORROPIA input includes total concentrations, temperature, and RH as well as the adjoint forcing vector, the elements of which correspond exactly to the output arrays of ISORROPIA (i.e., aqueous and gaseous partitionedspecies concentrations). During ANISORROPIA execution, branches and iterations are noted with inexpensive variable accumulation, and variable values are temporarily stored in memory during the forward calculations (Fig. 1, blue lines); the same procedures are then executed in reverse order while accumulating gradients in corresponding sensitivity calculations driven by the forcing vector (Fig. 1, orange lines). Thus, ANISORROPIA produces partial derivatives of the output species indicated in the forcing vector with respect to each input concentration (i.e., sum of aqueous and gaseous species concentration). If the adjoint forcing vector is null except for a single element equal to unity, ANISORROPIA produces the row of the Jacobian of ISORROPIA corresponding to the element equal to unity; for instance, if the element of the adjoint forcing vector corresponding to $\left[\mathrm{NH}_{4(\mathrm{aq})}^{+}\right]$is unity and all others zero, ANISORROPIA produces the array $\frac{\partial\left[\mathrm{NH}_{4 \mathrm{aq})}^{+}\right]}{\partial[\mathbf{X}]}$, where $[\mathbf{X}]$ is the array of concentrations of the sum of the aqueous and gaseous forms of species $X$, one of the total species tracked by ISORROPIA. Forward sensitivity analysis methods produce the column of the Jacobian corresponding to a selected $[Y]$; hence, a single execution of a forward sensitivity analysis method could yield, for example, the array $\frac{\partial[\mathbf{Y}]}{\partial\left[\mathrm{Total}_{2} \mathrm{SO}_{4}\right]}$, where $[\mathbf{Y}]$ is the array of concentrations of partitioned species, $Y$. In this way, the Jacobian produced by ANISORROPIA is compared directly to that determined by a forward sensitivity analysis method for model evaluation (Sect. 3.2).

For acidic cases (i.e., $R_{S}<2$ ), ISORROPIA iteratively resolves activity coefficients to convergence. The iterative nature of the forward solution is maintained in the adjoint of the acidic cases (Fig. 1a). Straightforward manipulation of ISORROPIA code was required to indicate which sensitivities should be traced by TAPENADE. The only modification to the forward solution is to increase the precision with which activity coefficients are calculated by default so that accurate sensitivity calculations can be obtained.

In the case of neutralized aerosol (i.e., $R_{S} \geq 2$ ), ISORROPIA evaluates whether equilibrium has been achieved by a selected saturation ratio. For instance, in the $\mathrm{NH}_{4}^{+}-\mathrm{SO}_{4}^{2-}-\mathrm{HSO}_{4}^{-}-\mathrm{NO}_{3}^{-}-\mathrm{H}_{2} \mathrm{O}$ aerosol system, all equations are solved successively so that only one equilibrium needs to be numerically solved, namely $\mathrm{NH}_{3(\mathrm{~g})}+\mathrm{H}_{2} \mathrm{O}_{(\mathrm{aq})} \leftrightharpoons$ $\mathrm{NH}_{4(\mathrm{aq})}^{+}+\mathrm{OH}_{(\mathrm{aq})}^{-}$; therefore, satisfactory equilibrium is achieved when $\frac{\left[\mathrm{NH}_{4(\mathrm{aq})}^{+}\right]\left[\mathrm{OH}_{\text {(aq) }}^{-}\right]}{K\left[\mathrm{NH}_{3(\mathrm{~g})}\right]}=1$, where, for example, $\left[\mathrm{NH}_{4(\mathrm{aq})}^{+}\right]$denotes the concentration of ammonium in mol
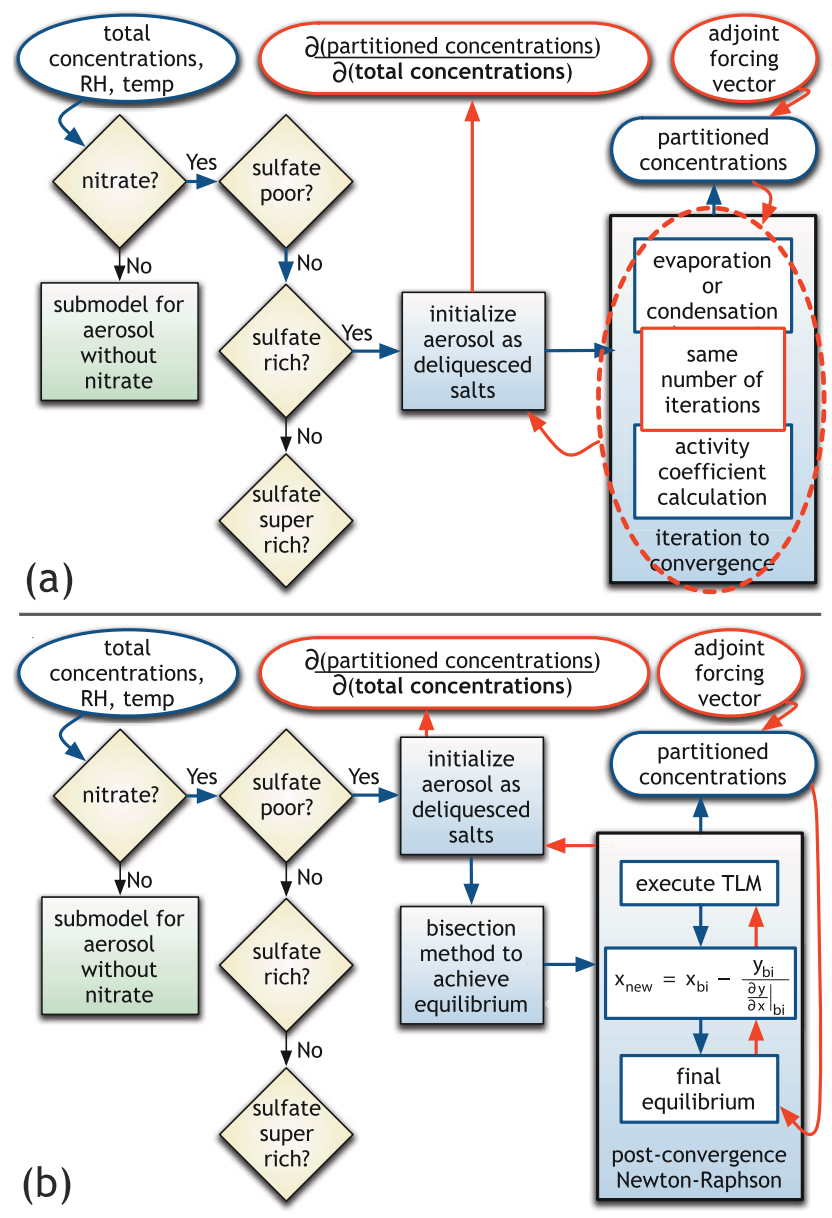

Fig. 1. Algorithmic flowchart of ANISORROPIA forward (blue) and adjoint (red) calculations. (a) The acidic aerosol solution algorithm is given for the cases where the molar ratio of positive ions (i.e., total ammonia and sodium) to total sulfate is less than two $\left(R_{S}<2\right)$; (b) for $R_{S} \geq 2$, the neutralized aerosol solution algorithm is shown.

$\mathrm{m}^{-3}$ and $K$ denotes the relevant equilibrium constant. Across the range of potential partitioned concentrations, the saturation ratio closely approximates the behavior of a step function owing to the very large change in species partitioning with small shifts in $\mathrm{pH}$. The stability of the bisection method ensures convergence to the root of $\frac{\left[\mathrm{NH}_{4(\mathrm{qq})}^{+}\right]\left[\mathrm{OH}_{(\mathrm{aq})}^{-}\right]}{K\left[\mathrm{NH}_{3(\mathrm{~g})}\right]}=$ 1 in ISORROPIA. The discontinuous nature of the bisection method required modification of the underlying model in order for sensitivities to be traced through the solution. First, for $R_{S} \geq 2$ in the $\mathrm{NH}_{4}^{+}-\mathrm{SO}_{4}^{2-}-\mathrm{HSO}_{4}^{-}-\mathrm{H}_{2} \mathrm{O}$ aerosol system, the bisection method was replaced with an iterative convergence algorithm similar to those employed for $R_{S}<2$ cases. Secondly, for $R_{S} \geq 2$ in the $\mathrm{NH}_{4}^{+}-\mathrm{SO}_{4}^{2-}$ $\mathrm{HSO}_{4}^{-}-\mathrm{NO}_{3}^{-}$and $\mathrm{NH}_{4}^{+}-\mathrm{SO}_{4}^{2-}-\mathrm{HSO}_{4}^{-}-\mathrm{NO}_{3}^{-}-\mathrm{Na}^{+}-\mathrm{Cl}^{-}-\mathrm{H}_{2} \mathrm{O}$ aerosol systems, the post-convergence Newton-Raphson (NR) method was implemented (Bartholomew-Biggs, 1998) 

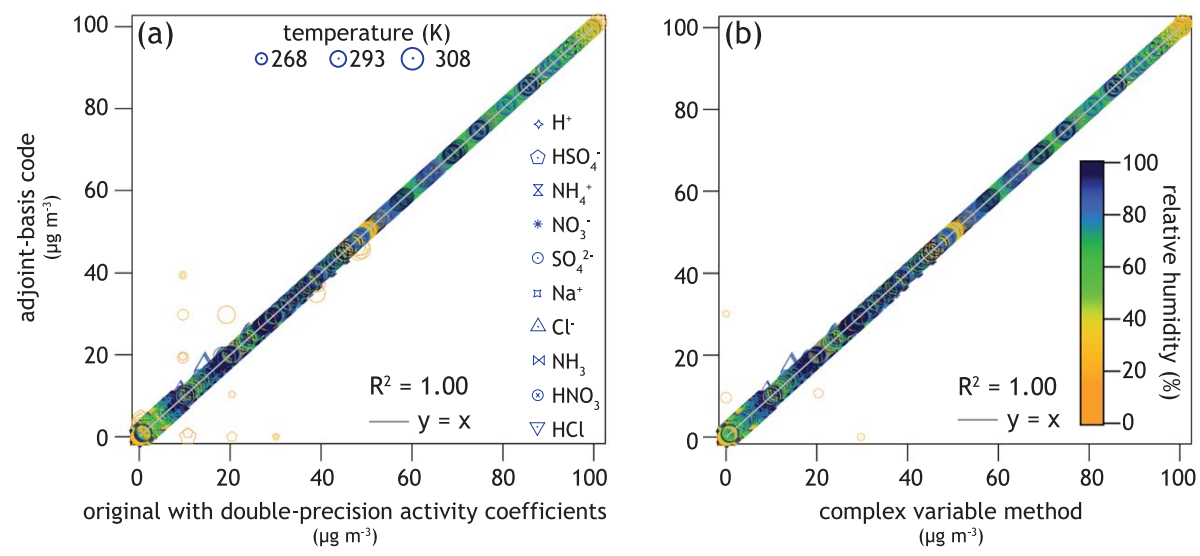

Fig. 2. Evaluation of concentrations of aqueous species in $\mu \mathrm{g} \mathrm{m}^{-3}$ produced by forward model augmented for adjoint development against (a) ISORROPIA v.2.1 with a modified double-precision activity coefficient module and (b) the complex variable version of ISORROPIA v.2.1 with double-precision activity coefficient module. The atmospherically relevant ranges of concentrations, $\mathrm{RH}$, and temperature evaluated are given in Sect. 3 of the text. In each case, the intercept and slope of the linear regression were negligibly different than 0 and 1 , respectively.

(Fig. 1b). Gradients required by N-R are calculated with TAPENADE-produced TLMs of the function being treated by bisection; that is, the chain rule is applied line-by-line to produce the sensitivity of the equilibrium equation of interest (e.g., $\frac{\left[\mathrm{NH}_{4(\mathrm{aq})}^{+}\right]\left[\mathrm{OH}_{(\mathrm{aq})}^{-}\right]}{K\left[\mathrm{NH}_{3(\mathrm{~g})}\right]}=1$ ) with respect to its input (e.g., moles of $\mathrm{NH}_{3(\mathrm{~g})}$ partitioning to the aerosol). The result of bisection serves as the initial guess of one iteration of the N-R method. By adding a differentiable calculation subsequent to the original algorithm, the stability of the bisection algorithm is maintained while providing the functionality necessary for adjoint calculations. It is sufficient to take the adjoint of this single step (Bartholomew-Biggs, 1998). The error system of ISORROPIA is augmented to note when the N-R calculation causes significant deviation from the bisection result. The forward and adjoint codes return this flag to the host model so that the thermodynamic partitioning of the select time step and grid cell can be consistently dismissed in concentration and sensitivity calculations.

\section{Evaluation of ANISORROPIA}

A two-part evaluation of ANISORROPIA was conducted. First, the partitioned concentrations given by ANISORROPIA were evaluated against ISORROPIA v.2.1 for an atmospherically relevant range of $\mathrm{RH}$ (5-95\%), temperature $(268-308 \mathrm{~K})$, and total concentrations to ensure that the forward calculations are not altered by the modifications of the code required to calculate the adjoint derivatives. Ranges of total concentrations were $1-50 \mu \mathrm{g} \mathrm{m}^{-3} \mathrm{H}_{2} \mathrm{SO}_{4}$; $0.2-9 \mu \mathrm{g} \mathrm{m}^{-3} \mathrm{NH}_{3} ; 0-16 \mu \mathrm{g} \mathrm{m}^{-3} \mathrm{HNO}_{3} ; 0-18 \mu \mathrm{g} \mathrm{m}^{-3} \mathrm{Na}$; and $0-30 \mu \mathrm{g} \mathrm{m}^{-3} \mathrm{HCl}$. Approximately 65000 sets of model input were evaluated, and ANISORROPIA processed $90 \%$ without producing an error code (Fig. 2). The stiffness of the numerical solution for equilibrium at high ionic concen- trations due to the metastable assumption sometimes leads to insufficient convergence for accurate adjoint sensitivity calculation causing an error. Errors can also arise from the post-convergence N-R step altering the equilibrium achieved by bisection. Optimal values for the ionic threshold (increased to 200 from the value of 100 used in ISORROPIA) and acceptable range for N-R deviation (unique to ANISORROPIA) were determined by extensive error assessment. For the convergent cases, ANISORROPIA concentrations are less than $0.1 \%$ different than results of the modified ISORROPIA v2.1 (Fig. $2, R^{2}=1.00$ ). Having ensured that the sensitivities would be evaluated for nearly identical simulated equilibrium concentrations, the accuracy of the adjoint sensitivities was assessed by comparison to sensitivities calculated using the complex variable method.

\subsection{The complex variable method}

The truncated Taylor series expansion of $F(x)$ about a point $\left(x_{0}\right)$ leads to the central finite difference approximation of $\frac{\partial F}{\partial x}$ with truncation error $O\left(h^{2}\right)$ given by

$\frac{\partial F}{\partial x}=\lim _{h \rightarrow 0} \frac{F\left(x_{0}+\frac{1}{2} h\right)-F\left(x_{0}-\frac{1}{2} h\right)}{h}$

where $F$ is a real analytic function and $h$ is a small, real perturbation. Lyness and Moler (1967) demonstrated that complex numbers are useful for numerical approximation of derivatives. Computational costs of their approach, which was based on Cauchy's integral theorem, limited application of the technique (Lantoine et al., 2010). Squire and Trapp (1998) developed an efficient complex step differentiation method which maintains machine precision in the derivative. For the complex analytic function $G(z)$, where $z$ is a complex 
argument, an analogous expression for $\frac{\partial G}{\partial z}$ with approximation error $O\left(h^{2}\right)$ arises:

$$
\frac{\partial G}{\partial z}=\lim _{h \rightarrow 0} \frac{\Im\left[G\left(z_{0}+i h\right)\right]}{h}
$$

where $i=\sqrt{-1}$ and $\mathfrak{\Im}$ selects the imaginary part of the argument (Squire and Trapp, 1998). The complex variable method (CVM) as introduced by Squire and Trapp (1998) eliminates subtraction cancellation and numerical round-off errors, the primary difficulties of numerical differentiation (Lyness and Moler, 1967).

To implement CVM in a FORTRAN-based numerical model such as ISORROPIA, variables are declared as COMPLEX rather than REAL, and intrinsic functions are modified to treat complex arguments (Giles and Pierce, 2000). This conversion is straightforward with the exception of the functions that must be approximated to accept COMPLEX arguments, such as the arccosine function, ACOS. ACOS is called within the analytical solution of the cubic polynomial $x^{3}+A_{1} x^{2}+A_{2} x+A_{3}=0$. CVM maintains the sensitivity information for variables in their imaginary part; thus, complex variables must be altered commensurately in the real and imaginary parts. Setting the total derivative to zero, $d f=\left.\frac{\partial f}{\partial x}\right|_{x=x_{0}} d x+\left.\sum_{i=1}^{3} \frac{\partial f}{\partial A_{i}}\right|_{x=x_{0}} d A_{i}=0$, where $x_{0}$ is the desired solution of the cubic polynomial, $A_{i}$ represents the coefficients of the polynomial, $d x=\Im\left(x_{0}\right)$, and $d A_{i}=\Im\left(A_{i}\right)$, yields $\frac{\partial x_{0}}{\partial A_{i}}=\frac{\Im\left(x_{0}\right)}{\Im\left(A_{i}\right)}$. Rather than using an alternate analytical solution to avoid calling ACOS, the imaginary part of $x_{0}$ was calculated independently. To do so, $\Im\left(A_{i}\right)$ were stored, and the desired real root calculated by the original function operating only on the real parts of $A_{i}$. The analytical total derivative of the cubic polynomial gives

$\Im\left(x_{0}\right)=\frac{-\left(x_{0}^{2}\right) \Im\left(A_{1}\right)-\left(x_{0}\right) \Im\left(A_{2}\right)-\Im\left(A_{3}\right)}{3 x_{0}^{2}+2 A_{1} x_{0}+A_{2}}$

by which $\Im\left(x_{0}\right)$ is obtained. This strategy is readily applicable in other CVM applications to similar calculations involving functions that must be approximated to treat a complex argument.

\subsection{Sensitivity comparison}

Although the accuracy of finite difference sensitivities is limited by round-off error, nonlinear effects, and solution discontinuities, these provide the most straightforward method of evaluating partial derivatives calculated by adjoints (Giles and Pierce, 2000); therefore, adjoint-based sensitivities are typically compared to those from the central finite difference method (e.g., Martien et al., 2006; Henze et al., 2007; Hakami et al., 2007). The highly nonlinear, discontinuous solution surface of ISORROPIA and associated subtraction cancellation errors rendered this method ineffective. For example, finite difference sensitivities of aqueous sulfate to total sulfate exceeded stoichiometric expectations for the

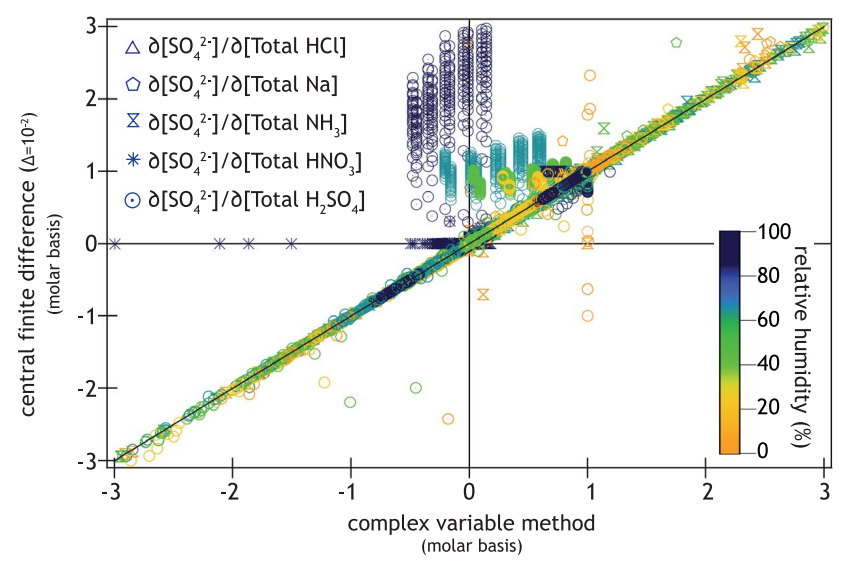

Fig. 3. Sensitivities from the central finite difference method with a delta value of $10^{-2}$ compared against sensitivities from the complex variable method with a perturbation of $10^{-18} i$. The line $y=x$ is plotted for reference (solid black). Deviations from stoichiometric expectations in finite difference sensitivities revealed that the finite difference approach would not suffice to evaluate ANISORROPIA sensitivities.

same input for which the CVM found reasonable sensitivities (Fig. 3). To overcome this issue, CVM is used for evaluation of ANISORROPIA sensitivities.

The adjoint sensitivities from ANISORROPIA are compared to those from CVM over the same evaluation range which was employed for the concentrations described in Sect. 3 (Fig. 4). Thirty-five sensitivities of the aerosol concentration (model output: $\mathrm{Cl}_{(\mathrm{aq})}^{-}, \mathrm{H}_{(\mathrm{aq})}^{+}, \mathrm{HSO}_{4(\mathrm{aq})}^{-}, \mathrm{Na}_{(\mathrm{aq})}^{+}$, $\left.\mathrm{NH}_{4(\mathrm{aq})}^{+}, \mathrm{NO}_{3(\mathrm{aq})}^{-}, \mathrm{SO}_{4(\mathrm{aq})}^{2-}\right)$ to the sum of gaseous and aerosol concentrations (model input: total chloride, total nitrate, total sulfate, total ammonium, and total sodium) were evaluated for each of the aqueous aerosol species with respect to each aerosol precursor. Testing other sensitivities (e.g., gaseous concentration with respect to total species) is also possible but redundant. The ANISORROPIA-produced sensitivities are compared against CVM results (Fig. 4). The black solid line represents $y=x$ and depicts the region of perfect agreement; approximately $10^{5}$ points are represented in each of the six sensitivity comparisons. Despite some deviation at very low relative humidities and lower temperatures, the level of agreement in the results verifies that the adjoint sensitivities are consistent with the model sensitivities for the majority of atmospherically relevant conditions.

\subsection{Computational efficiency}

The computational time required for execution of ANISORROPIA concentration and adjoint sensitivity calculations was assessed by comparing the elapsed CPU time against ISORROPIA v.2.1 with a double-precision activity coefficient module. Both models were executed with the same convergence criteria (e.g., relative difference of activity coefficients 

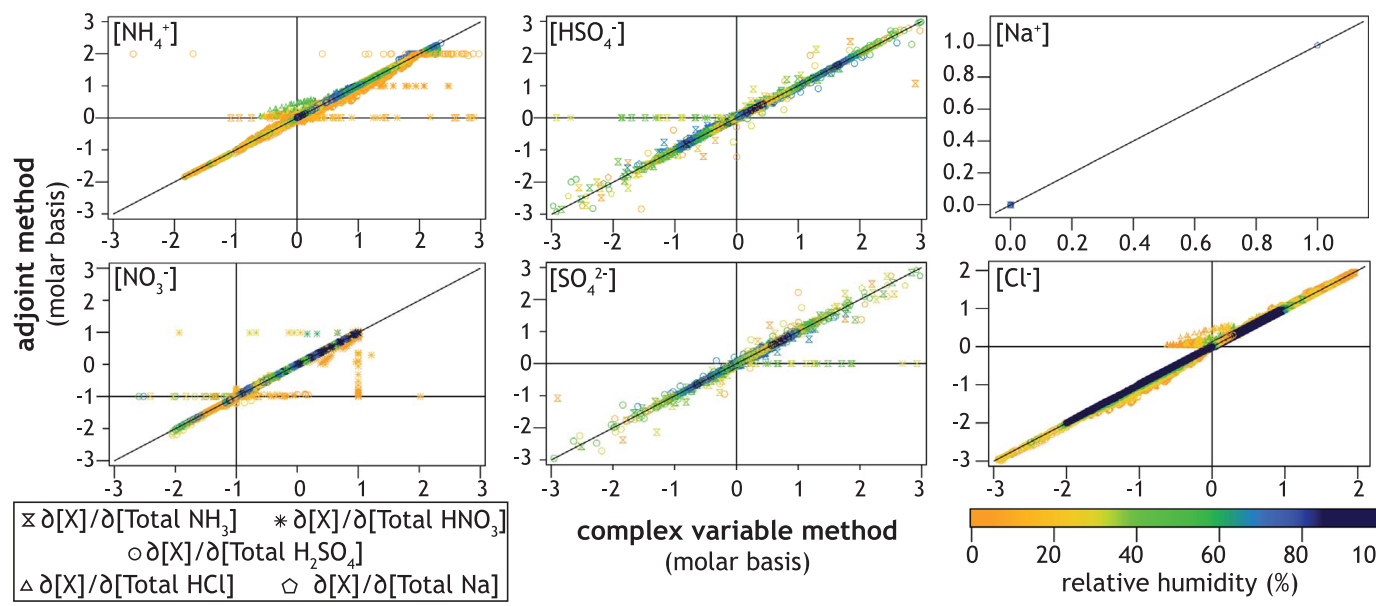

complex variable method (molar basis)

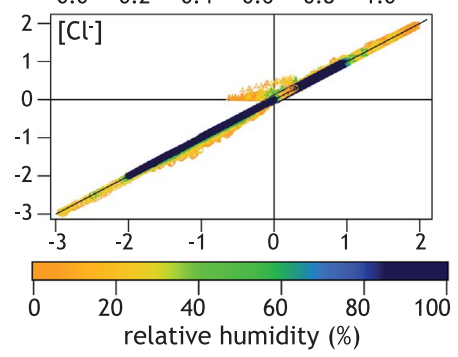

Fig. 4. The sensitivities of aqueous species with respect to the total amount of each aerosol species on a molar basis from ANISORROPIA are shown against those from CVM for the range of aerosol precursor concentrations, temperature, and RH outlined in the text (Sect. 3).

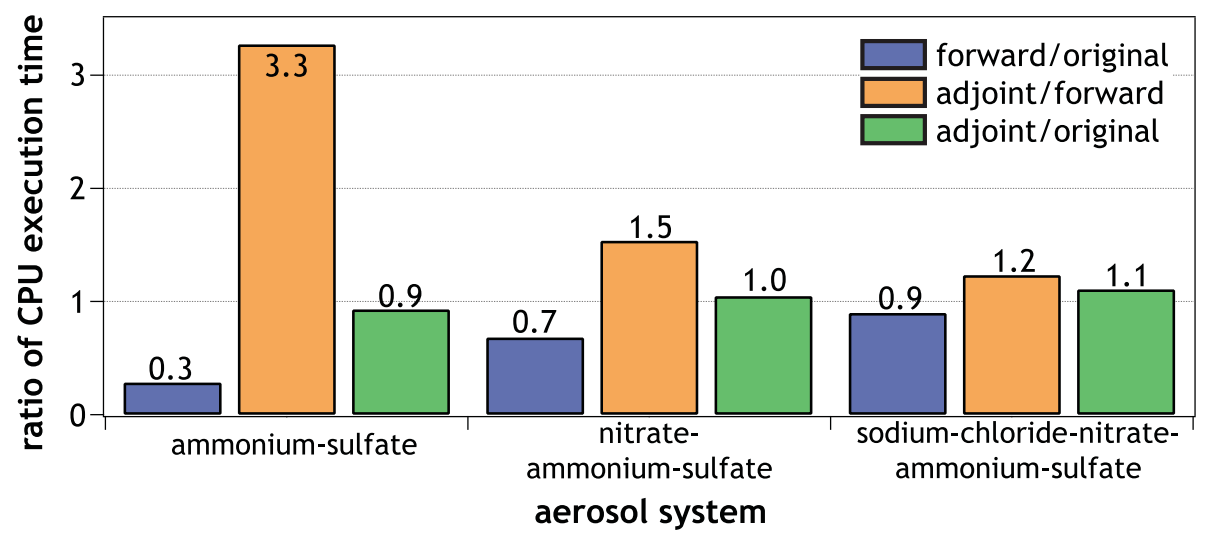

Fig. 5. The ratios comparing CPU execution time for the calculations of ANISORROPIA forward concentrations (forward), ANISORROPIA adjoint sensitivities (adjoint), and ISORROPIA v.2.1 forward concentrations with double precision activity coefficient calculations (original) are shown. Experiments were designed to elucidate the ratios for each of the aerosol systems treated in ANISORROPIA (SO ${ }_{4}^{2-}$ $\mathrm{HSO}_{4}^{-}-\mathrm{NH}_{4}^{+}-\mathrm{H}_{2} \mathrm{O} ; \mathrm{NO}_{3}^{-}-\mathrm{SO}_{4}^{2-}-\mathrm{HSO}_{4}^{-}-\mathrm{NH}_{4}^{+}-\mathrm{H}_{2} \mathrm{O} ; \mathrm{Na}^{+}-\mathrm{Cl}^{-}-\mathrm{NO}_{3}^{-}-\mathrm{SO}_{4}^{2-}-\mathrm{HSO}_{4}^{-}-\mathrm{NH}_{4}^{+}-\mathrm{H}_{2} \mathrm{O}$ ). The forward/original comparison reveals the reduced time required because of algorithmic changes necessary for adjoint development.

from previous iteration $<10^{-10}$ ). Modeling experiments were designed to examine the three different aerosol systems individually because algorithmic modifications were unique in the three systems. All written output was suppressed so that calculations, not variable writing processes, were evident in the timing comparisons. The assessment was conducted on a $2.93 \mathrm{GHz}$ Intel Core i7 processor running Mac OS X v10.7.2; source code was compiled with O3 optimization by the Intel Fortran compiler.

The atmospherically relevant evaluation range (Sect. 3) bounded the input for the timing experiments. Only in the $\mathrm{NH}_{4}^{+}-\mathrm{SO}_{4}^{2-}-\mathrm{HSO}_{4}^{-}-\mathrm{H}_{2} \mathrm{O}$ does the adjoint exceed a three-fold increase in computational time over the concentration calculations with the adjoint-based code (Fig. 5), which is far less than the theoretical upper limit of a factor of five (Griewank, 1989). Even in this case, an algorithmic change to one of the three sub-regimes causes a significant decrease in the concentration calculation cost such that the adjoint sensitivities still require less time than the original model concentration calculations (adjoint/original). The more comprehensive $\mathrm{NH}_{4}^{+}-\mathrm{SO}_{4}^{2-}-\mathrm{HSO}_{4}^{-}-\mathrm{NO}_{3}^{-}-\mathrm{H}_{2} \mathrm{O}$ and $\mathrm{NH}_{4}^{+}-\mathrm{SO}_{4}^{2-}$ $\mathrm{HSO}_{4}^{-}-\mathrm{NO}_{3}^{-}-\mathrm{Na}^{+}-\mathrm{Cl}^{-}-\mathrm{H}_{2} \mathrm{O}$ aerosol systems were less modified, leading to computational costs similar to those of the original model for concentrations (forward/original). The computational efficiency of the post-convergence $\mathrm{N}$ $\mathrm{R}$ approach exhibits less than a doubling of computational time for the adjoint sensitivities over concentrations (adjoint/forward). Convergence criteria optimization through error analysis significantly improved the computational efficiency of ANISORROPIA for both concentration and sensitivity calculations. ANISORROPIA requires similar increases in computational time as the gas-phase adjoint of 

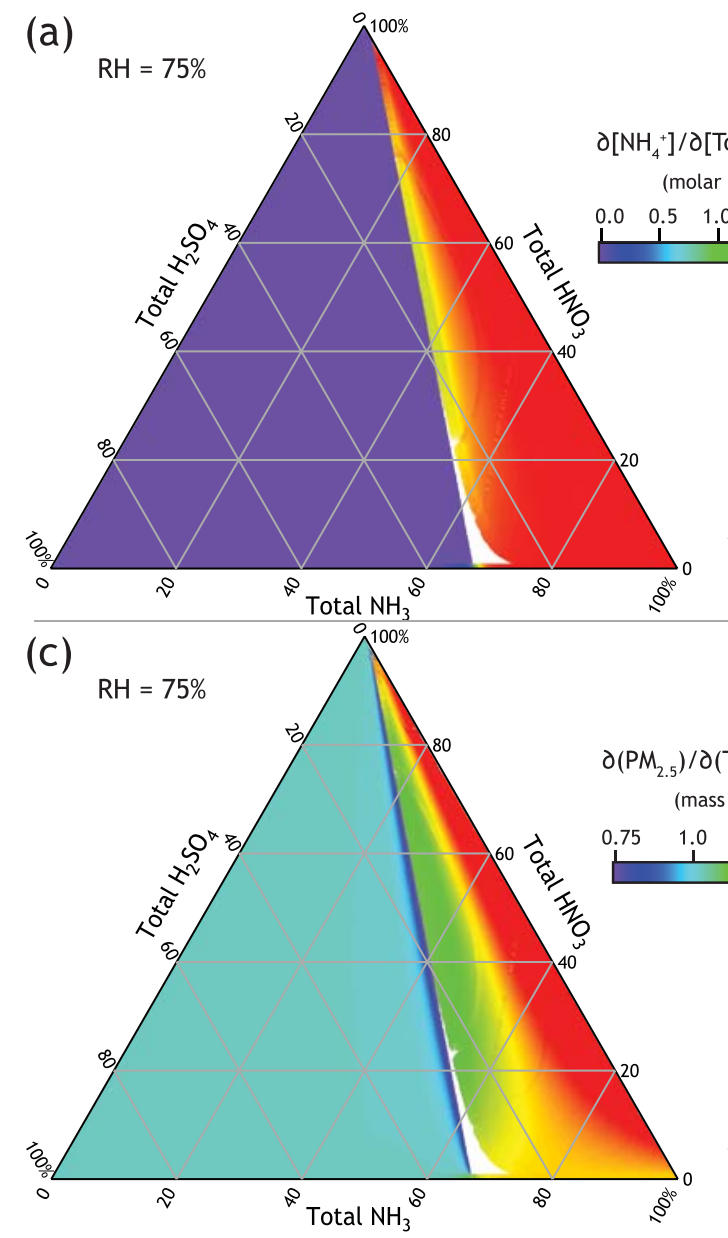

(b)

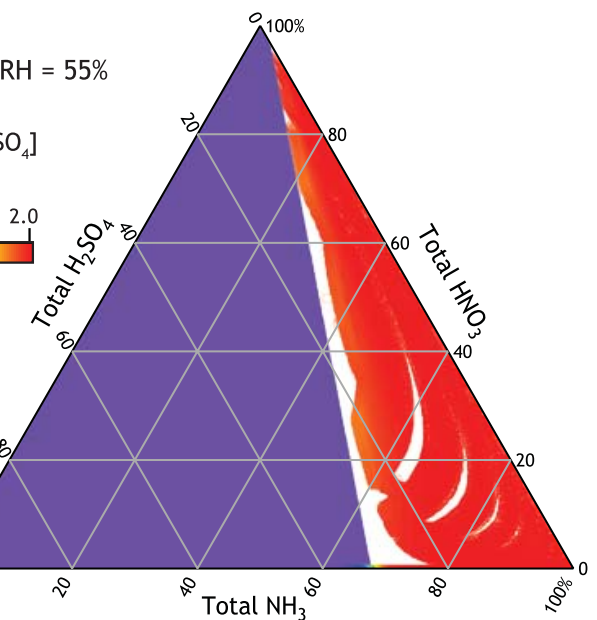

(d)

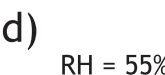

Fig. 6. ANISORROPIA-produced $\frac{\partial\left[\mathrm{NH}_{4(\mathrm{aq})}^{+}\right]}{\partial\left[\mathrm{Total} \mathrm{H}_{2} \mathrm{SO}_{4}\right]}$ on a molar basis (a,b) and $\frac{\partial\left(\mathrm{PM}_{2.5, \mathrm{dry}}\right)}{\partial\left(\mathrm{Total}_{2} \mathrm{SO}_{4}\right)}$ on a mass basis $(\mathbf{c}, \mathbf{d})$ for the $\mathrm{NH}_{4}^{+}-\mathrm{SO}_{4}^{2-}-\mathrm{HSO}_{4}^{-}$$\mathrm{NO}_{3}^{-}-\mathrm{H}_{2} \mathrm{O}$ aerosol system at $\mathrm{RH}$ of $75 \%(\mathbf{a}, \mathbf{c})$ and $55 \%(\mathbf{b}, \mathbf{d})$ and a temperature of $300 \mathrm{~K}$. The axes convey the percent a total species (adjacent label) contributes to the molar composition of the system. White space denotes error occurrence.

CMAQ and the adjoint of GEOS-Chem, which are 2 and 1.5 times the original model, respectively (Hakami et al., 2007; Henze et al., 2007). As for memory requirements, the only values necessary from the adjoint forward execution are total species concentrations, $\mathrm{RH}$, and temperature; all values needed for adjoint calculations are recomputed or stored internally in allocatable arrays using the efficient PUSH/POP mechanism of TAPENADE (Hascoët and Pascual, 2004).

\section{Application}

ANISORROPIA has been developed for application within the adjoints of CTMs from regional (e.g., Community Multiscale Air Quality model (CMAQ), Byun and Schere, 2006) to global scales (e.g., GEOS-Chem, Henze et al., 2007); in these frameworks, its potential can be fully realized. Nevertheless, applied independently of a CTM, ANISORROPIA provides an efficient, reliable method of determining the sen- sitivity of dry, inorganic fine mode aerosol to changes in total concentrations of sulfate, ammonia, nitrate, sodium, and chloride for deliquesced aerosol. The input required is exactly the same as the forward mode of ISORROPIA (i.e., total concentrations, $\mathrm{RH}$, temperature). ANISORROPIA is used to identify sensitivity regimes over a broad range of atmospherically relevant concentrations (Sect. 4.1). Then, conditions from in situ measurements of the inorganic composition of aerosols and quantities of the gas phase precursors $\mathrm{NH}_{3(\mathrm{~g})}, \mathrm{HNO}_{3(\mathrm{~g})}$, and $\mathrm{HCl}_{(\mathrm{g})}$ from two distinct urban environments (Atlanta, Georgia, USA, and Mexico City, D.F., Mexico) are processed to characterize the urban $\mathrm{PM}_{2.5}$ responsiveness to anthropogenically emitted species (Sect. 4.2).

\subsection{Sensitivity regimes}

ANISORROPIA is applied to produce sensitivities for the partitioning of $\mathrm{NH}_{3(\mathrm{~g})}$ in response to the addition of 


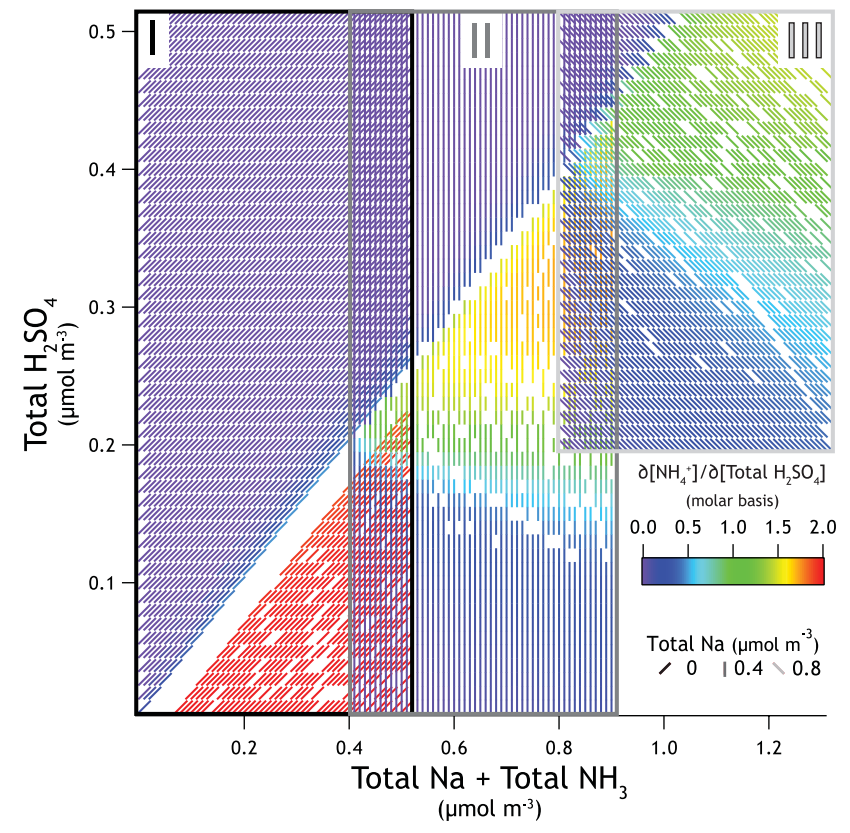

Fig. 7. ANISORROPIA-produced $\frac{\partial\left[\mathrm{NH}_{4(\mathrm{aq})}^{+}\right]}{\partial\left[\mathrm{Total}_{2} \mathrm{SO}_{4}\right]}$ (molar basis) for the $\mathrm{NH}_{4}^{+}-\mathrm{SO}_{4}^{2-}-\mathrm{HSO}_{4}^{-}-\mathrm{NO}_{3}^{-}-\mathrm{Na}^{+}-\mathrm{Cl}^{-}-\mathrm{H}_{2} \mathrm{O}$ aerosol system at a $\mathrm{RH}$ of $40 \%$ and a temperature of $300 \mathrm{~K}$. The total $\mathrm{HCl}$ is $0.8 \mu \mathrm{mol} \mathrm{m}{ }^{-3}$, and the total $\mathrm{HNO}_{3}$ is $0.01 \mu \mathrm{mol} \mathrm{m}{ }^{-3}$. Region I corresponds to $0 \mu \mathrm{mol} \mathrm{m}{ }^{-3}$ of total $\mathrm{Na}$, Region II to $0.4 \mu \mathrm{mol} \mathrm{m} \mathrm{m}^{-3}$ of total $\mathrm{Na}$, and Region III to $0.8 \mu \mathrm{mol} \mathrm{m}{ }^{-3}$ of total Na. Note the transition in sensitivity at a ratio of 2 moles of positive ions (total $\left.\mathrm{NH}_{3}+\mathrm{Na}\right)$ to 1 mole of total $\mathrm{H}_{2} \mathrm{SO}_{4}\left(R_{S}=2\right)$. The increasing gradient from left to right in Regions II and III demonstrates the contribution of positive ions from $\mathrm{Na}_{(\mathrm{aq})}^{+}$initially balancing $\mathrm{SO}_{4(\mathrm{aq})}^{2-}$ (i.e., low $\frac{\partial\left[\mathrm{NH}_{4(\mathrm{aq})}^{+}\right]}{\partial\left[\mathrm{Total}_{2} \mathrm{SO}_{4}\right]}$ ) and the increasing contribution of $\mathrm{NH}_{4(\mathrm{aq})}^{+}$to the charge balance with more negative ions present.

$\mathrm{H}_{2} \mathrm{SO}_{4(\mathrm{~g})}$ and then for fine mode, dry aerosol (i.e., $\mathrm{PM}_{2.5}$ ) in response to the same at $300 \mathrm{~K}$ (Fig. 6). Throughout much of the atmosphere, ammonium contributes a significant fraction of positive ions in aerosol (Seinfeld and Pandis, 2006). The condensation of two moles of $\mathrm{NH}_{3(\mathrm{~g})}$ for each additional mole of $\mathrm{H}_{2} \mathrm{SO}_{4(\mathrm{~g})}$ in an air parcel can be expressed as $\frac{\partial\left[\mathrm{NH}_{4 \mathrm{aq}}^{+}\right]}{\partial\left[\mathrm{Total}_{4} \mathrm{SO}_{4}\right]}=2$ on a molar basis. At $55 \% \mathrm{RH}$, the $\partial\left[\mathrm{NH}_{4(\mathrm{aq})}^{+}\right]$ $\frac{2}{\left.\partial \text { Total }^{2} \mathrm{H}_{2} \mathrm{SO}_{4}\right]}$ given by ANISORROPIA demonstrates this behavior when the ratio of total ammonia to sulfate exceeds two (Fig. 6b). White space in the ternary diagram denotes occurrence of an error. When the ratio of total ammonia to sulfate is less than two, $\frac{\partial\left[\mathrm{NH}_{4(\mathrm{qq})}^{+}\right]}{\partial\left[\mathrm{Total}_{2} \mathrm{SO}_{4}\right]}=0$ on a molar basis whether significant water is present (Fig. 6a) or not (Fig. 6b). In the presence of $\mathrm{HNO}_{3(\mathrm{~g})}$ and enough water for it to partition significantly to aerosol, $\frac{\partial\left[\mathrm{NH}_{4(\mathrm{aq})}^{+}\right]}{\partial\left[\mathrm{Total}_{2} \mathrm{SO}_{4}\right]}$ ranges between zero and two reflecting the buffering effect of $\mathrm{HNO}_{3(\mathrm{~g})}$, which evaporates from the aerosol as the $\mathrm{H}_{2} \mathrm{SO}_{4(\mathrm{~g})}$ condenses (Fig. 6a).
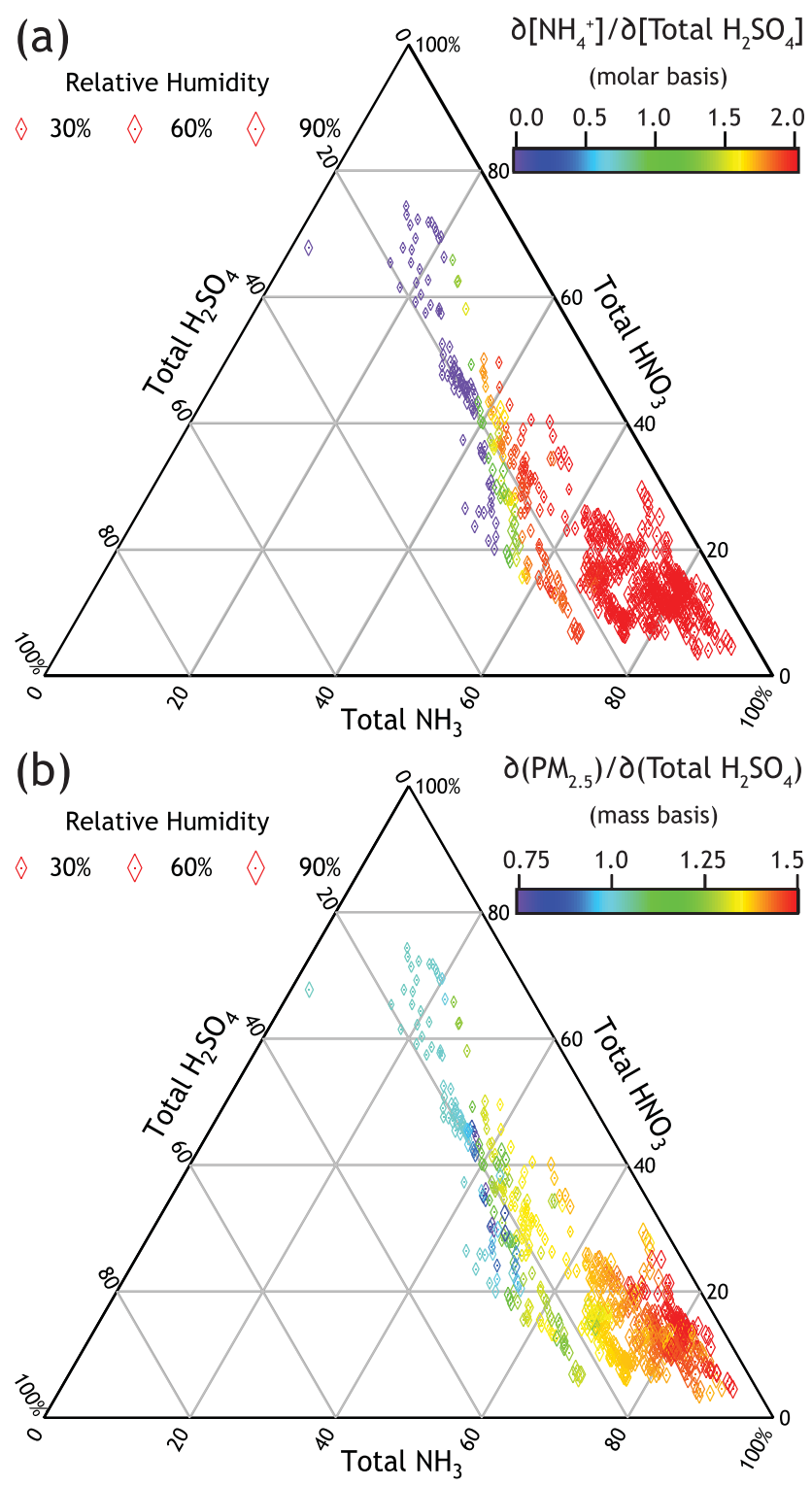

Fig. 8. ANARChE data processed with ANISORROPIA reveal Atlanta $\frac{\partial\left[\mathrm{NH}_{4(\mathrm{aq})}^{+}\right]}{\partial\left[\text { Total } \mathrm{H}_{2} \mathrm{SO}_{4}\right]}$ (molar basis) (a) and $\frac{\partial\left(\mathrm{PM}_{2.5, \text { dry }}\right)}{\partial\left(\mathrm{Total}_{2} \mathrm{SO}_{4}\right)}$ (mass basis) (b) in July-August 2002. RH ranges from $25 \%-99 \%$ and temperature from $293 \mathrm{~K}$ to $310 \mathrm{~K}$.

ANISORROPIA results elucidate the dry aerosol mass changes due to the addition of $1 \mu \mathrm{g} \mathrm{H}_{2} \mathrm{SO}_{4(\mathrm{~g})}$ at $75 \%$ and $55 \% \mathrm{RH}$ and $300 \mathrm{~K} . \frac{\partial\left(\mathrm{PM}_{2.5, \mathrm{dry}}\right)}{\partial\left(\mathrm{Total} \mathrm{H}_{2} \mathrm{SO}_{4}\right)}$, where $\left(\right.$ Total $\left.\mathrm{H}_{2} \mathrm{SO}_{4}\right)$ is the mass-based concentration of all sulfate in the system, ranges from 0.75 to slightly greater than 1.5 on a mass basis. The molar masses of sulfate $\left(98 \mathrm{~g} \mathrm{~mol}^{-1}\right)$, ammonium $\left(18 \mathrm{~g} \mathrm{~mol}^{-1}\right)$, and nitrate $\left(62 \mathrm{~g} \mathrm{~mol}^{-1}\right)$ are important for understanding these results. Adding one $\mu \mathrm{g}$ of sulfate to an acidic aerosol should cause an equivalent increase in the dry aerosol mass (Fig. 6c, d). Given that neutralized aerosol at 


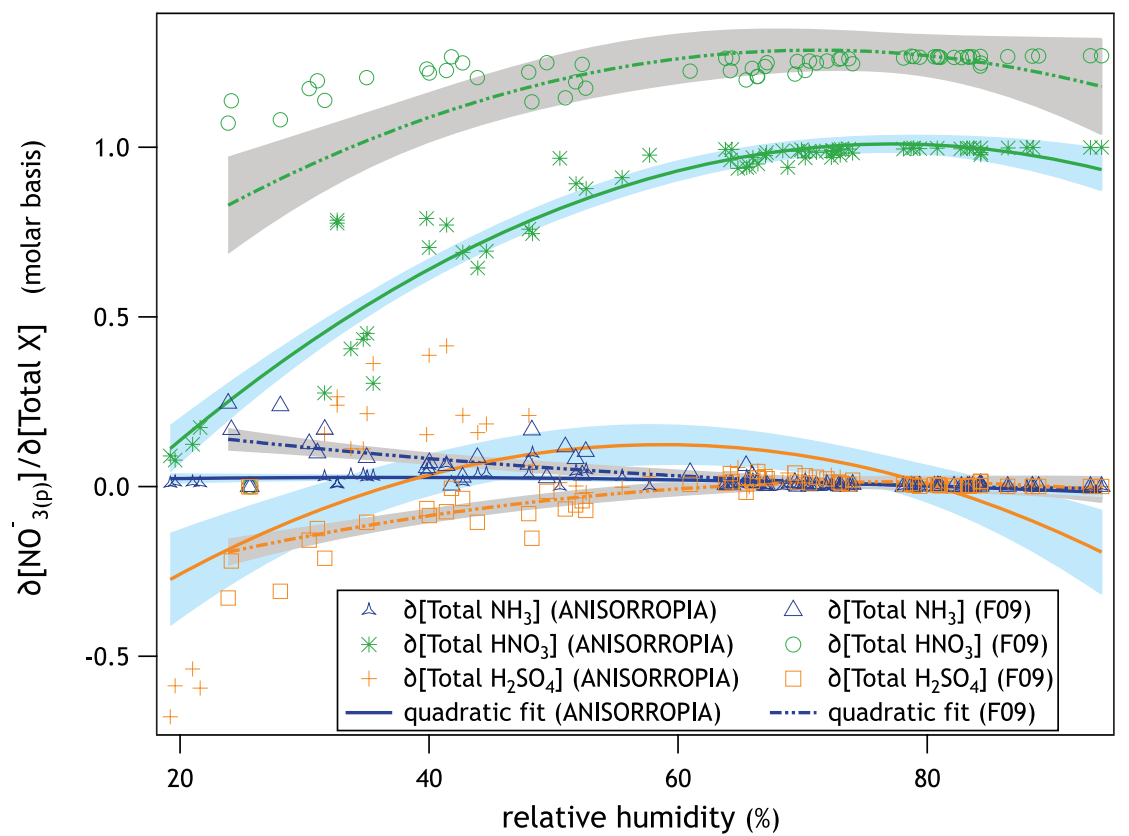

Fig. 9. The ANISORROPIA-produced $\frac{\partial\left[\mathrm{NO}_{3(\mathrm{aq})}^{-}\right.}{\partial\left[\mathrm{Total}_{\mathrm{HNO}}\right]}, \frac{\partial \mathrm{NO}_{3(\mathrm{aq})}^{-}}{\partial\left[\mathrm{Total} \mathrm{NH}_{3}\right]}$, and $\frac{\partial \mathrm{NO}_{3(\mathrm{aq})}^{-}}{\partial\left[\mathrm{Total}_{2} \mathrm{SO}_{4}\right]}$ values are plotted alongside backward finite difference sensitivities from Fountoukis et al. (2009) (F09) for MILAGRO observations in Mexico City. The quadratic fits to the sensitivity data are shown to direct the eye with the $95 \%$ confidence interval given by the shaded bands about the fit lines. Solid lines and light blue shading correspond to ANISORROPIA sensitivities; dashed lines and gray shading correspond to F09 sensitivities. With the exception of the fit about $\partial \mathrm{NO}_{3(\mathrm{aq})}^{-}$

$\frac{\partial \mathrm{NO}_{3(\mathrm{aq})}}{\partial\left[\mathrm{Total}_{2} \mathrm{SO}_{4}\right]}$, ANISORROPIA has tighter bands than F09, indicating less scatter in the results due to the direct computation of sensitivity about the desired input. ANISORROPIA characterizes the sensitivity of Mexico City aerosol nitrate similarly to the full forward model employed by F09.

lower RH has $\frac{\partial\left[\mathrm{NH}_{4 \mathrm{aq}}^{+}\right]}{\partial\left[\mathrm{Total}_{2} \mathrm{SO}_{4}\right]} \simeq 2$ on a molar basis, the condensation of $\mathrm{NH}_{3(\mathrm{~g})}$ and $\mathrm{H}_{2} \mathrm{SO}_{4}(\mathrm{~g})$ govern the $\frac{\partial\left(\mathrm{PM}_{2.5, \mathrm{dry}}\right)}{\partial\left(\mathrm{Total}_{2} \mathrm{SO}_{4}\right)}$ of 1.37 on a mass basis (Fig. 6d). When aerosol nitrate buffers the system by evaporation upon condensation of $\mathrm{H}_{2} \mathrm{SO}_{4(\mathrm{~g})}$, $\frac{\partial\left(\mathrm{PM}_{2.5, \mathrm{dry}}\right)}{\partial\left(\mathrm{Total}_{2} \mathrm{SO}_{4}\right)}$ drops below 1 on a mass basis, in part due to the higher molar mass of nitrate than ammonium, as shown in a small region of Fig. 6c. Low temperatures $(\sim 250 \mathrm{~K})$ and high concentrations of total nitrate relative to total ammonium and sulfate can lead to negative values of $\frac{\partial\left(\mathrm{PM}_{2.5, \mathrm{dry}}\right)}{\partial\left(\mathrm{Total}_{2} \mathrm{SO}_{4}\right)}$, which is caused by the ratio of molar masses of these species and their relative capacity for inducing water uptake (not shown). This variability underscores the importance of sensitivity analysis for air quality.

ANISORROPIA results for the $\mathrm{NH}_{4}^{+}-\mathrm{SO}_{4}^{2-}-\mathrm{HSO}_{4}^{-}-\mathrm{NO}_{3}^{-}$$\mathrm{Na}^{+}-\mathrm{Cl}^{-}-\mathrm{H}_{2} \mathrm{O}$ aerosol system reveal even more complex sensitivity relationships quite clearly (Fig. 7). $\frac{\partial\left[\mathrm{NH}_{4 \mathrm{aq}}^{+}\right]}{\partial\left[\mathrm{Total} \mathrm{H}_{2} \mathrm{SO}_{4}\right]}$ is shown for a system with $30 \mathrm{\mu g} \mathrm{m}^{-3}$ total $\mathrm{HCl}$ and $0.63 \mu \mathrm{g} \mathrm{m}^{-3}$ total $\mathrm{HNO}_{3}$ at $40 \% \mathrm{RH}$ and $300 \mathrm{~K}$. The abscissa corresponds to the sum of the total amounts of the species producing positive ions, $\mathrm{Na}$ and $\mathrm{NH}_{3}$. The ordinate corresponds to the total $\mathrm{H}_{2} \mathrm{SO}_{4}$ in the system. Differing amounts of sodium in the system define the three regions, which overlap slightly to show the effect of sodium on the sensitivity. Region I (forward-slanted hash marks), where sodium is absent, demonstrates the primary role of $\mathrm{NH}_{4(\mathrm{aq})}^{+}$in neutralizing sulfate. The sensitivity of 2 on a molar basis for $\frac{\partial\left[\mathrm{NH}_{4 \mathrm{aq}}^{+}\right]}{\partial\left[\mathrm{Total}_{2} \mathrm{SO}_{4}\right]}$ persists when $R_{S} \geq 2$; however, if $R_{S}<2, \frac{\partial\left[\mathrm{NH}_{4}^{+} \text {(aq) }\right.}{\partial\left[\mathrm{Total}_{2} \mathrm{SO}_{4}\right]}=0$. This behavior is consistent with that demonstrated in the $\mathrm{NH}_{4}^{+}-\mathrm{SO}_{4}^{2-}-\mathrm{HSO}_{4}^{-}-\mathrm{NO}_{3}^{-}-\mathrm{H}_{2} \mathrm{O}$ system (Fig. 6). Region II (vertical hash marks) reveals the system sensitivity when $\mathrm{Na}_{(\text {(aq) }}^{+}$contributes to neutralizing sulfate. At the far left edge of Region II, $\mathrm{Na}_{(\mathrm{aq})}^{+}$constitutes the majority of the positive ions; therefore, the $\frac{\partial\left[\mathrm{NH}_{4 \mathrm{aq}}^{+}\right]}{\partial\left[\mathrm{Total}_{2} \mathrm{SO}_{4}\right]}$ is negligible. Moving to the right across Region II, the concentration of positively charged $\mathrm{Na}_{(\mathrm{aq})}^{+}$ions is exceeded by $\mathrm{SO}_{4(\mathrm{aq})}^{2-}$ ions, and $\frac{\partial\left[\mathrm{NH}_{4(\mathrm{aq})}^{+}\right]}{\partial\left[\mathrm{Total}_{2} \mathrm{SO}_{4}\right]}$ increases correspondingly. Finally, in Region III, the same reduced value of $\frac{\partial\left[\mathrm{NH}_{4(\mathrm{aqq}}^{+}\right]}{\partial\left[\mathrm{Total}_{2} \mathrm{SO}_{4}\right]}$ appears with a dampened rate of increase of $\mathrm{NH}_{4(\mathrm{aq})}^{+}$contribution to positively charged ions due to the large contribution from $\mathrm{Na}_{(\text {aq) }}^{+}$ and minor buffering by $\mathrm{NO}_{3(\mathrm{aq})}^{-}$and $\mathrm{Cl}_{(\mathrm{aq})}^{-}$. ANISORROPIA could also be applied at different $\mathrm{RH}$, temperature, or compositions to reveal similarly meaningful sensitivity regimes. 


\subsection{Observed conditions}

\subsubsection{Atlanta, Georgia, USA}

The Atlanta Aerosol Nucleation and Real-Time Characterization Experiment (Atlanta-ANARChE) in July and August of 2002 included measurements of $\mathrm{NH}_{3(\mathrm{~g})}$ and $\mathrm{HNO}_{3(\mathrm{~g})}$ via two distinct methods of chemical ionization mass spectrometry (Neuman et al., 2003; Nowak et al., 2006). The ground campaign was conducted at Jefferson Street in midtown Atlanta, one of the sites of the ongoing Southeast Aerosol Research and Characterization (SEARCH) study (Hansen et al., 2003) and the location of the Atlanta Supersite (Solomon et al., 2003). SEARCH instrumentation measured sulfate $\left(\mathrm{SO}_{4(\mathrm{aq})}^{2-}\right)$, ammonium $\left(\mathrm{NH}_{4(\mathrm{aq})}^{+}\right)$, and nitrate $\left(\mathrm{NO}_{3(\mathrm{aq})}^{-}\right)$concentrations with continuous 1-min resolution coincident with the gas phase measurements (Edgerton et al., 2006). Meteorological data collected include $\mathrm{RH}$ and temperature. Nowak et al. (2006) demonstrated the level of accuracy of ISORROPIA in predicting the partitioned concentrations, which also governs the accuracy of the aerosol sensitivities of ANISORROPIA.

ANARChE data were collected in the range of 25-99\% $\mathrm{RH}$ and $293-310 \mathrm{~K}$. Results find that $\frac{\partial\left[\mathrm{NH}_{4(\mathrm{qq})}^{+}\right]}{\partial\left[\mathrm{Total}_{2} \mathrm{SO}_{4}\right]}=2$ on a molar basis while the molar composition is $5-20 \%$ total $\mathrm{H}_{2} \mathrm{SO}_{4}$ and $60-95 \%$ total $\mathrm{NH}_{3}$ (Fig. 8a). $\frac{\partial\left[\mathrm{NH}_{4(\mathrm{qq})}^{+}\right]}{\partial\left[\mathrm{Total}_{2} \mathrm{SO}_{4}\right]}$ is negligible when total $\mathrm{H}_{2} \mathrm{SO}_{4}$ makes up 10-20\% and total $\mathrm{NH}_{3}$ makes up 20-40\% of the molar composition, which is consistent with sensitivities shown in Fig. 6a,b. The calculated $\frac{\partial\left(\mathrm{PM}_{2.5, \mathrm{dry}}\right)}{\partial\left(\mathrm{Total}_{2} \mathrm{SO}_{4}\right)}$ often exceeds 1.3 on a mass basis for this time period, owing to the condensation of $\mathrm{NH}_{3(\mathrm{~g})}$ required to neutralize $\mathrm{H}_{2} \mathrm{SO}_{4}$ and the co-condensation of $\mathrm{NH}_{3}(\mathrm{~g})$ and $\mathrm{HNO}_{3(\mathrm{~g})}$ (as deliquesced $\left.\mathrm{NH}_{4} \mathrm{NO}_{3}\right) \cdot \frac{\partial\left(\mathrm{PM}_{2.5, \text { dry }}\right)}{\partial\left(\text { Total } \mathrm{H}_{2} \mathrm{SO}_{4}\right)}$ decreases to unity for acidic aerosol, as $\mathrm{NH}_{3(\mathrm{~g})}$ is virtually zero.

\subsubsection{Mexico City, D.F., Mexico}

Comprehensive measurements from the Megacity Initiative: Local and Global Research Observations (MILAGRO) campaign during March of 2006 (Molina et al., 2010) facilitate the characterization of aerosol sensitivities for a very different urban air mass than that found in Atlanta due to the presence of sodium and chloride as well as significantly higher $\mathrm{NH}_{3(\mathrm{~g})}$ concentrations. The campaign included three ground sites with one in the urban center at the Instituto Mexicano del Petróleo (T0 site), another at the Universidad Tenológica de Tecámac in the state of Mexico (T1 site), and a third site at Rancho La Bisnaga in the state of Hidalgo (T2 site). For this investigation, data are analyzed for the period of 21-30 March 2006, from the T1 site, which is typically downwind of Mexico City. Measurements provide the $\mathrm{PM}_{2.5}$ concentrations of $\mathrm{SO}_{4(\mathrm{p})}^{2-}, \mathrm{NH}_{4(\mathrm{p})}^{+}$, $\mathrm{NO}_{3(\mathrm{p})}^{-}, \mathrm{Na}_{(\mathrm{p})}^{+}, \mathrm{Cl}_{(\mathrm{p})}^{-}, \mathrm{Ca}_{(\mathrm{p})}^{2+}, \mathrm{K}_{(\mathrm{p})}^{+}$, and $\mathrm{Mg}_{(\mathrm{p})}^{2+}$; gaseous concentrations of $\mathrm{NH}_{3(\mathrm{~g})}, \mathrm{HNO}_{3(\mathrm{~g})}$, and $\mathrm{HCl}_{(\mathrm{g})}$, and the ambient
RH and temperature (Fountoukis et al., 2009). The $\mathrm{PM}_{2.5}$ ionic concentrations were measured by a Particle Into Liquid Sampler (PILS) with a 6-min integrated sampling period and a new chromatogram begun every $17 \mathrm{~min}$ (Orsini et al., 2003). Gaseous concentrations of $\mathrm{NH}_{3(\mathrm{~g})}$ were obtained with a quantum cascade laser (QCL) spectrometer and $\mathrm{HNO}_{3(\mathrm{~g})}$ concentrations were deduced from the volatile nitrate (i.e., $\mathrm{HNO}_{3(\mathrm{~g})}+\mathrm{NH}_{4} \mathrm{NO}_{3(\mathrm{p})}$ ) concentrations acquired with the thermal dissociation-laser induced fluorescence of nitrogen oxides (TD-LIF) (Day et al., 2002; Farmer et al., 2006). More details regarding data acquisition, uncertainty analysis, and quality assurance are given by Fountoukis et al. (2009).

As shown by Fountoukis et al. (2009) and since $R_{S}>2$, $\frac{\partial\left[\mathrm{NH}_{4 \mathrm{aq}}^{+}\right]}{\partial\left[\mathrm{Total}_{2} \mathrm{SO}_{4}\right]}=2$ on a molar basis except at $\mathrm{RH}$ less than the mutual deliquescence $\mathrm{RH}$ of $\mathrm{NaNO}_{3(\mathrm{~s})}$ and $\mathrm{NH}_{4} \mathrm{NO}_{3(\mathrm{~s})}$ (i.e., approximately $50 \% \mathrm{RH}$ ). To investigate a more variable component of the $\mathrm{NH}_{4}^{+}-\mathrm{SO}_{4}^{2-}-\mathrm{HSO}_{4}^{-}-\mathrm{NO}_{3}^{-}-\mathrm{Na}^{+}-\mathrm{Cl}^{-}$$\mathrm{H}_{2} \mathrm{O}$ aerosol system, the sensitivity of aerosol $\mathrm{NO}_{3(\mathrm{aq})}^{-}$is explored as in Fountoukis et al. (2009) (Fig. 9). The Fountoukis et al. (2009) sensitivities are calculated by backward finite difference with explicit treatment of crustal species and the possibility for aerosol species to condense into solid salts. ANISORROPIA evaluates the same input by treating the crustal species $\mathrm{Mg}_{(\mathrm{p})^{2+}}$ and $\mathrm{K}_{(\mathrm{p})^{+}}$as equivalent moles of sodium based on ionic charge (Moya et al., 2001) and $\mathrm{Ca}_{(\mathrm{p})}{ }^{2+}$ as insoluble $\mathrm{CaSO}_{4(\mathrm{~s})}$. Additionally, aerosol are assumed to be deliquesced, as is common in CTMs and leads to minor differences (Fountoukis et al., 2009). In an environment with excess $\mathrm{NH}_{3(\mathrm{~g})}$, $\frac{\partial\left[\mathrm{NO}_{3(\mathrm{aq})}^{-}\right]}{\partial\left[\mathrm{Total}_{3} \mathrm{HNO}_{3}\right]}$ is expected to be 1 on a molar basis unless insufficient aerosol water is present to absorb the additional $\mathrm{HNO}_{3(\mathrm{~g})}$. ANISORROPIA produces this expected sensitivity (Fig. 9, green asterisks) and with less scatter than the backward finite difference sensitivities given by Fountoukis et al. (2009). The greater scatter about the polynomial fit line for the F09 sensitivities is expected due to the limited accuracy of the finite difference method (Sect. 3.2). Furthermore, backward finite difference sensitivities exceed the expected value of $1 \mathrm{~mol} \mathrm{~mol}^{-1}$ for $\mathrm{RH}$ greater than $50 \%$, which ANISORROPIA more accurately represents. Complementary to this sensitivity are the values of $\frac{\partial\left[\mathrm{NO}_{3(\mathrm{aq})}^{-}\right]}{\partial\left[\mathrm{Total}_{3}\right]}$ and $\frac{\partial\left[\mathrm{NO}_{3(\mathrm{aq})}^{-}\right]}{\partial\left[\mathrm{Total}_{2} \mathrm{SO}_{4}\right]}$, which are expected to be zero. Again, reduced scatter above $50 \% \mathrm{RH}$ is evident for ANISORROPIA results. The backward finite difference results for $\frac{\partial\left[\mathrm{NO}_{3}^{-}(\mathrm{aq})\right]}{\partial\left[\mathrm{Total} \mathrm{N}_{3}\right]}$ are significantly different than the central finite difference results with the same perturbation size, which align much more closely with ANISORROPIA $\frac{\partial\left[\mathrm{NO}_{3}^{-} \text {(aq) }\right.}{\partial\left[\mathrm{Total} \mathrm{N}_{3}\right]}$ values for 30 $50 \% \mathrm{RH}$ (not shown). ANISORROPIA reveals that aerosol nitrate in Mexico City is primarily sensitive to the addition of $\mathrm{HNO}_{3(\mathrm{~g})}$, a conclusion congruent with the findings of Fountoukis et al. (2009). 


\section{Conclusions}

The increasing measurements of aerosol composition from field campaigns and observations of aerosol precursor concentrations from satellites provide a substantial opportunity to advance the predictive capabilities of CTMs. One efficient method of gleaning valuable information from these data is to solve the inverse problem by applying the adjoint method to optimize emissions parameters, initial conditions, or boundary conditions of the CTM. Specifically, with a CTM adjoint, the computational cost of optimization no longer scales with the number of parameters being optimized, which is essential for spatially and temporally variable aerosol precursor emissions. Furthermore, receptor-oriented sensitivity analysis, possible only with a CTM adjoint, elucidates the relative impacts of emissions sources on air quality, human health, and climate metrics with temporal and spatial resolution.

This work presents the development and independent applications of ANISORROPIA, the adjoint of the thermodynamic aerosol model ISORROPIA for the $\mathrm{Na}^{+}{ }_{-} \mathrm{SO}_{4}^{2-}$ $\mathrm{HSO}_{4}^{-}-\mathrm{NH}_{4}^{+}-\mathrm{NO}_{3}^{-}-\mathrm{Cl}^{-}-\mathrm{H}_{2} \mathrm{O}$ aerosol system. Development involved modification of the forward model code and application of the automatic differentiation tool, TAPENADE (Hascoët and Pascual, 2004). Verification of ANISORROPIA required development of a complex variable version of ISORROPIA and evaluation against sensitivities produced by it, which are more reliable than the finite difference method. Further development of ANISORROPIA will extend its capacity to treat the crustal species included in ISORROPIA II $\left(\mathrm{Mg}^{2+}, \mathrm{Ca}^{2+}\right.$, and $\left.\mathrm{K}^{+}\right)$as well as the reverse mode execution for the purpose of calculating dynamic equilibrium. ANISORROPIA is used to reveal the sensitivity regimes of aerosol ammonium to sulfate and fine mode, dry aerosol mass to sulfate for a wide range of atmospherically relevant conditions. ANISORROPIA is employed to characterize the sensitivity regimes of the distinct urban air masses of Atlanta and Mexico City. Receptor-oriented sensitivity analysis with CTM adjoints including ANISORROPIA shall be useful for investigating the relative contribution of specific emissions sources to radiative forcing and air quality. Within the adjoints of regional and global CTMs, ANISORROPIA can provide the ability to trace the impact of the major components of inorganic aerosol and their precursors back to the emissions source. Finally, ANISORROPIA enables assimilation of observations of inorganic aerosol precursor and aerosol concentrations in an inverse modeling framework.

Acknowledgements. SLC was supported by an NSF Graduate Research Fellowship, a Georgia Tech Institute Fellowship, and an Eastman Chemical Summer Graduate Fellowship. DKH acknowledges support from NASA Applied Sciences Program. AH acknowledges support from the National Sciences and Engineering Research Council of Canada. This work was partially funded by ConocoPhillips Company, the American Petroleum Institute, and US EPA STAR Grant RD-833866. Its contents are solely the responsibility of the grantee and do not necessarily represent the official views of the US EPA. Further, US EPA does not endorse the purchase of any commercial products or services mentioned in the publication.

Edited by: J. H. Seinfeld

\section{References}

Amundson, N. R., Caboussat, A., He, J. W., Martynenko, A. V., Savarin, V. B., Seinfeld, J. H., and Yoo, K. Y.: A new inorganic atmospheric aerosol phase equilibrium model (UHAERO), Atmos. Chem. Phys., 6, 975-992, doi:10.5194/acp-6-975-2006, 2006.

Ansari, A. and Pandis, S.: Response of inorganic PM to precursor concentrations, Environ. Sci. Technol., 32, 2706-2714, 1998.

Ansari, A. and Pandis, S.: Prediction of multicomponent inorganic atmospheric aerosol behavior, Atmos. Environ., 33, 745-757, 1999a.

Ansari, A. and Pandis, S.: An analysis of four models predicting the partitioning of semivolatile inorganic aerosol components, Aerosol Sci. Technol., 31, 129-153, 1999 b.

Bartholomew-Biggs, M.: Using Forward Accumulation for Automatic Differentiation of Implicitly-Defined Functions, Comp. Optim. App., 9, 65-84, 1998.

Bessagnet, B., Hodzic, A., Vautard, R., Beekmann, M., Cheinet, S., Honoré, C., Liousse, C., and Rouil, L.: Aerosol modeling with CHIMERE-preliminary evaluation at the continental scale, Atmos. Environ., 38, 2803-2817, 2004.

Bey, I., Jacob, D., Yantosca, R., Logan, J., Field, B., Fiore, A., Li, Q., Liu, H., Mickley, L., and Schultz, M.: Global modeling of tropospheric chemistry with assimilated meteorology - Model description and evaluation, J. Geophys. Res., 106, 23073-23095, 2001.

Binkowski, F. and Roselle, S.: Models-3 Community Multiscale Air Quality (CMAQ) model aerosol component - 1. Model description, J. Geophys. Res., 108, 4183-4201, 2003.

Byun, D. and Schere, K.: Review of the Governing Equations, Computational Algorithms, and Other Components of the Models-3 Community Multiscale Air Quality (CMAQ) Modeling System, Appl. Mechan. Rev., 59, 51-77, 2006.

Capaldo, K., Pilinis, C., and Pandis, S.: A computationally efficient hybrid approach for dynamic gas/aerosol transfer in air quality models, Atmos. Environ., 34, 3617-3627, 2000.

Carmichael, G., Tang, Y., Kurata, G., Uno, I., Streets, D., Woo, J.-H., Huang, H., Yienger, J., Lefer, B., Shetter, R., Blake, D., Atlas, E., Fried, A., Apel, E., Eisele, F., Cantrell, C., Avery, M., Barrick, J., Sachse, G., Brune, W., Sandholm, S., Kondo, Y., Singh, H., Talbot, R., Bandy, A., Thorton, D., Clarke, A., and Heikes, B.: Regional-scale chemical transport modeling in support of the analysis of observations obtained during the TRACE-P experiment, J. Geophys. Res., 108, 8823-8851, doi:10.1029/2002JD003117, 2003.

Chai, T., Carmichael, G. R., Sandu, A., Tang, Y., and Daescu, D. N.: Chemical data assimilation of Transport and Chemical Evolution over the Pacific (TRACE-P) aircraft measurements, J. Geophys. Res., 111, D02301, doi:10.1029/2005JD005883, 2006.

Clegg, S., Brimblecombe, P., and Wexler, A.: Thermodynamic Model of the System $\mathrm{H}^{+}-\mathrm{NH}_{4}^{+}-\mathrm{Na}^{+}-\mathrm{SO}_{4}^{2-}-\mathrm{NO}_{3}^{-}-\mathrm{Cl}^{-}-\mathrm{H}_{2} \mathrm{O}$ at 
298.15 K, J. Phys. Chem. A, 102, 2155-2171, 1998.

Cohen, M. D., Flagan, R. C., and Seinfeld, J. H.: Studies of concentrated electrolyte solutions using the electrodynamic balance. 2 . Water activities for mixed-electrolyte solutions, J. Phys. Chem., 91, 4575-4582, 1987.

Dassios, K. and Pandis, S.: The mass accommodation coefficient of ammonium nitrate aerosol, Atmos. Environ., 33, 2993-3003, 1999.

Day, D. A., Wooldridge, P., Dillon, M., Thornton, J., and Cohen, R.: A thermal dissociation laser-induced fluorescence instrument for in situ detection of $\mathrm{NO}_{2}$, peroxy nitrates, alkyl nitrates, and $\mathrm{HNO}_{3}$, J. Geophys. Res., 107, 4046-4060, doi:10.1029/2001JD000779, 2002.

Dubovik, O., Lapyonok, T., Kaufman, Y. J., Chin, M., Ginoux, P., Kahn, R. A., and Sinyuk, A.: Retrieving global aerosol sources from satellites using inverse modeling, Atmos. Chem. Phys., 8, 209-250, doi:10.5194/acp-8-209-2008, 2008.

Dunker, A. M.: The decoupled direct method for calculating sensitivity coefficients in chemical kinetics, J. Chem. Phys., 81, 23852393, 1984.

Edgerton, E., Hartsell, B., Saylor, R., Jansen, J., Hansen, D., and Hidy, G.: The Southeastern Aerosol Research and Characterization Study, Part 3: Continuous measurements of fine particulate matter mass and composition, J. Air Waste Manag. Assoc., 56, 1325-1341, 2006.

Elbern, H., Schmidt, H., and Ebel, A.: Variational data assimilation for tropospheric chemistry modeling, J. Geophys. Res., 102, 15967-15985, doi:10.1029/97JD01213, 1997.

Elbern, H., Schmidt, H., Talagrand, O., and Ebel, A.: 4D-variational data assimilation with an adjoint air quality model for emission analysis, Environ. Model. Soft., 15, 539-548, 2000.

ENVIRON: User's Guide to the Comprehensive Air Quality Model with Extensions (CAMx), Novato, California, USA, 1.10 edn., 1997.

ENVIRON: Comprehensive Air Quality Model with extensions User's Guide, Novato, California, USA, 5.3 edn., 2010.

Farmer, D. K., Wooldridge, P. J., and Cohen, R. C.: Application of thermal-dissociation laser induced fluorescence (TD-LIF) to measurement of $\mathrm{HNO}_{3}, \sum$ alkyl nitrates, $\sum$ peroxy nitrates, and $\mathrm{NO}_{2}$ fluxes using eddy covariance, Atmos. Chem. Phys., 6, 3471-3486, doi:10.5194/acp-6-3471-2006, 2006.

Fisher, M. and Lary, D. J.: Lagrangian four-dimensional variational data assimilation of chemical species, Q. J. Roy Meteorol. Soc., 121, 1681-1704, 1995.

Forster, P., Ramaswamy, V., Artaxo, P., Berntsen, T., Betts, R., Fahey, D., Haywood, J., Lean, J., Lowe, D., and Myhre, G.: Climate Change 2007: The Physical Science Basis. Contribution of Working Group I, in: Fourth Assessment Report of the Intergovernmental Panel on Climate Change, Cambridge University Press, 2007.

Fountoukis, C. and Nenes, A.: ISORROPIA II: a computationally efficient thermodynamic equilibrium model for $\mathrm{K}^{+}$$\mathrm{Ca}^{+2}-\mathrm{Mg}^{+2}-\mathrm{NH}_{4}^{+}-\mathrm{Na}^{+}-\mathrm{SO}_{4}^{2-}-\mathrm{NO}_{3}^{-}-\mathrm{Cl}^{-}-\mathrm{H}_{2} \mathrm{O}$ aerosols, Atmos. Chem. Phys., 7, 4639-4659, doi:10.5194/acp-7-4639-2007, 2007.

Fountoukis, C., Nenes, A., Sullivan, A., Weber, R., Van Reken, T., Fischer, M., Matas, E., Moya, M., Farmer, D., and Cohen, R. C.: Thermodynamic characterization of Mexico City aerosol during MILAGRO 2006, Atmos. Chem. Phys., 9, 2141-2156, doi:10.5194/acp-9-2141-2009, 2009.

Gaydos, T., Pinder, R., Koo, B., Fahey, K., Yarwood, G., and Pandis, S.: Development and application of a three-dimensional aerosol chemical transport model, PMCAMx, Atmos. Environ., 41, 2594-2611, 2007.

Giles, M. and Pierce, N.: An introduction to the adjoint approach to design, Flow Turb. Comb., 65, 393-415, 2000.

Griewank, A.: On automatic differentiation, in: Mathematical Programming: Recent Developments and Applications, edited by Iri, M. and Tanabe, K., 83-108, Kluwer Academic Publishers, Argonne National Laboratory, 1989.

Hakami, A., Henze, D., Seinfeld, J., Chai, T., Tang, Y., Carmichael, G., and Sandu, A.: Adjoint inverse modeling of black carbon during the Asian Pacific Regional Aerosol Characterization Experiment, J. Geophys. Res., 110, D14301, doi:10.1029/2004JD005671, 2005.

Hakami, A., Seinfeld, J., Chai, T., Tang, Y., Carmichael, G., and Sandu, A.: Adjoint sensitivity analysis of ozone nonattainment over the continental United States, Environ. Sci. Technol., 40, 3855-3864, 2006.

Hakami, A., Henze, D., Seinfeld, J., Singh, K., Sandu, A., Kim, S., Byun, D., and Li, Q.: The Adjoint of CMAQ, Environ. Sci. Technol., 41, 7807-7817, doi:10.1021/es070944p, 2007.

Hansen, D. A., Edgerton, E. S., Hartsell, B. E., Jansen, J. J., Kandasamy, N., Hidy, G. M., and Blanchard, C. L.: The Southeastern Aerosol Research and Characterization Study: Part 1-Overview, J. Air Waste Manag. Assoc., 53, 1460-1471, 2003.

Harvie, C. E., Møller, N., and Weare, J. H.: The prediction of mineral solubilities in natural waters: The $\mathrm{Na}-\mathrm{K}-\mathrm{Mg}-\mathrm{Ca}-\mathrm{H}-\mathrm{Cl}-\mathrm{SO}_{4}-$ $\mathrm{OH}-\mathrm{HCO}_{3}-\mathrm{CO}_{3}-\mathrm{CO}_{2}-\mathrm{H}_{2} \mathrm{O}$ system to high ionic strengths at $25^{\circ} \mathrm{C}$, Geochimica et Cosmochimica Acta, 48, 723-751, 1984.

Hascoët, L. and Pascual, V.: TAPENADE 2.1 User's Guide, Tech. rep., INRIA Sophia Antipolis, Sophia Antipolis Cedex, 2004.

Heintzenberg, J.: Fine particles in the global troposphere: A review, Tellus B, 41B, 149-160, 1989.

Henze, D., Seinfeld, J., Liao, W., Sandu, A., and Carmichael, G.: Inverse modeling of aerosol dynamics: Condensational growth, J. Geophys. Res., 109, D14201, doi:10.1029/2004JD004593, 2004.

Henze, D. K., Hakami, A., and Seinfeld, J. H.: Development of the adjoint of GEOS-Chem, Atmos. Chem. Phys., 7, 2413-2433, doi:10.5194/acp-7-2413-2007, 2007.

Henze, D. K., Seinfeld, J. H., and Shindell, D. T.: Inverse modeling and mapping US air quality influences of inorganic $\mathrm{PM}_{2.5}$ precursor emissions using the adjoint of GEOS-Chem, Atmos. Chem. Phys., 9, 5877-5903, doi:10.5194/acp-9-5877-2009, 2009.

Huebert, B., Bates, T., Russell, P., Shi, G., Kim, Y., Kawamura, K., Carmichael, G., and Nakajima, T.: An overview of ACEAsia: Strategies for quantifying the relationships between Asian aerosols and their climatic impacts, J. Geophys. Res., 108, 86338653, doi:10.1029/2003JD003550, 2003.

Jacobson, M.: Studying the effects of calcium and magnesium on size-distributed nitrate and ammonium with EQUISOLV II, Atmos. Environ., 33, 3635-3649, 1999.

Jacobson, M., Tabazadeh, A., and Turco, R.: Simulating equilibrium within aerosols and nonequilibrium between gases and aerosols, J. Geophys. Res., 101(D4), 9079-9091, 1996.

Kaminski, T., Heimann, M., and Giering, R.: A coarse grid three- 
dimensional global inverse model of the atmospheric transport. 2. Inversion of the transport of $\mathrm{CO}_{2}$ in the $1980 \mathrm{~s}$, J. Geophys. Res., 104, 18535-18553, 1999.

Kaynak, B., Hu, Y., Martin, R. V., Sioris, C. E., and Russell, A. G.: Comparison of weekly cycle of $\mathrm{NO}_{2}$ satellite retrievals and $\mathrm{NO}_{\mathrm{x}}$ emission inventories for the continental United States, J. Geophys. Res., 114, D05302, doi:10.1029/2008JD010714, 2009.

Kelly, J. T., Bhave, P. V., Nolte, C. G., Shankar, U., and Foley, K. M.: Simulating emission and chemical evolution of coarse seasalt particles in the Community Multiscale Air Quality (CMAQ) model, Geosci. Model Dev., 3, 257-273, doi:10.5194/gmd-3257-2010, 2010.

Kim, Y. P., Seinfeld, J. H., and Saxena, P.: Atmospheric GasAerosol Equilibrium I. Thermodynamic Model, Aerosol Sci. Tech., 19, 157-181, 1993a.

Kim, Y. P., Seinfeld, J. H., and Saxena, P.: Atmospheric GasAerosol Equilibrium II. Analysis of Common Approximations and Activity Coefficient Calculation Methods, Aerosol Sci. Tech., 19, 182-198, 1993b.

Klimont, Z. and Streets, D.: Emission inventories and projections for assessing hemispheric or intercontinental transport, in: Air Pollution Studies No. 16, edited by: Keating, T. and Zuber, A., United Nations, Economic Commission for Europe, New York and Geneva, 2007.

Koo, B., Dunker, A., and Yarwood, G.: Implementing the Decoupled Direct Method for Sensitivity Analysis in a Particulate Matter Air Quality Model, Environ. Sci. Technol., 41, 2847-2854, 2007.

Kopacz, M., Jacob, D. J., Henze, D. K., Heald, C. L., Streets, D. G., and Zhang, Q.: Comparison of adjoint and analytical Bayesian inversion methods for constraining Asian sources of carbon monoxide using satellite (MOPITT) measurements of CO columns, J. Geophys. Res., 114, D04305, doi:10.1029/2007JD009264, 2009.

Kopacz, M., Mauzerall, D. L., Wang, J., Leibensperger, E. M., Henze, D. K., and Singh, K.: Origin and radiative forcing of black carbon transported to the Himalayas and Tibetan Plateau, Atmos. Chem. Phys., 11, 2837-2852, doi:10.5194/acp-11-28372011, 2011.

Kukkonen, J., Olsson, T., Schultz, D. M., Baklanov, A., Klein, T., Miranda, A. I., Monteiro, A., Hirtl, M., Tarvainen, V., Boy, M., Peuch, V.-H., Poupkou, A., Kioutsioukis, I., Finardi, S., Sofiev, M., Sokhi, R., Lehtinen, K. E. J., Karatzas, K., San Jos, R., Astitha, M., Kallos, G., Schaap, M., Reimer, E., Jakobs, H., and Eben, K.: A review of operational, regional-scale, chemical weather forecasting models in Europe, Atmos. Chem. Phys., 12, 1-87, doi:10.5194/acp-12-1-2012, 2012.

Lamb, R., Chen, W., and Seinfeld, J.: Numerico-Empirical Analyses of Atmospheric Diffusion Theories, J. Atmosph. Sci., 32, 1794-1807, 1975.

Lantoine, G., Russell, R., and Dargent, T.: Using Multicomplex Variables for Automatic Computation of High-Order Derivatives, American Astronautical Society/American Institute of Aeronautics and Astronautics Space Flight Mechanics Meeting, San Diego, California, USA, 14-17 February 2010, Paper AAS 10218, 2010

Lyness, J. and Moler, C.: Numerical differentiation of analytic functions, SIAM J. Num. Anal., 4(2), 202-210, 1967.

Malm, W. C., Sisler, J. F., Huffman, D., Eldred, R. A., and Cahill,
T. A.: Spatial and seasonal trends in particle concentration and optical extinction in the United States, J. Geophys. Res., 99, 1347-1370, 1994.

Marchuk, G.: Numerical solution of the problem of dynamics of atmosphere and ocean, Gidrometeoizdat, Leningrad, 1974.

Martien, P. and Harley, R.: Adjoint sensitivity analysis for a threedimensional photochemical model: Application to Southern California, Environ. Sci. Technol., 40, 4200-4210, 2006.

Martien, P. T., Harley, R. A., and Cacuci, D. G.: Adjoint Sensitivity Analysis for a Three-Dimensional Photochemical Model: Implementation and Method Comparison, Environ. Sci. Technol., 40, 2663-2670, 2006.

Mendoza-Dominguez, A. and Russell, A.: Estimation of emission adjustments from the application of four-dimensional data assimilation to photochemical air quality modeling, Atmos. Environ., 35, 2879-2894, 2001.

Meng, Z. and Seinfeld, J.: Time scales to achieve atmospheric gasaerosol equilibrium for volatile species, Atmos. Environ., 30, 2889-2900, 1996.

Menut, L., Vautard, R., Beekmann, M., and Honoré, C.: Sensitivity of photochemical pollution using the adjoint of a simplified chemistry-transport model, J. Geophys. Res., 105(D12), 1537915402, 2000.

Metzger, S. and Lelieveld, J.: Reformulating atmospheric aerosol thermodynamics and hygroscopic growth into fog, haze and clouds, Atmos. Chem. Phys., 7, 3163-3193, doi:10.5194/acp-73163-2007, 2007.

Metzger, S., Mihalopoulos, N., and Lelieveld, J.: Importance of mineral cations and organics in gas-aerosol partitioning of reactive nitrogen compounds: case study based on MINOS results, Atmos. Chem. Phys., 6, 2549-2567, doi:10.5194/acp-6-25492006, 2006.

Molina, L. T., Madronich, S., Gaffney, J. S., Apel, E., de Foy, B., Fast, J., Ferrare, R., Herndon, S., Jimenez, J. L., Lamb, B., Osornio-Vargas, A. R., Russell, P., Schauer, J. J., Stevens, P. S., Volkamer, R., and Zavala, M.: An overview of the MILAGRO 2006 Campaign: Mexico City emissions and their transport and transformation, Atmos. Chem. Phys., 10, 8697-8760, doi:10.5194/acp-10-8697-2010, 2010

Moya, M., Ansari, A., and Pandis, S. N.: Partitioning of nitrate and ammonium between the gas and particulate phases during the 1997 IMADA-AVER study, Atmos. Environ., 35, 1791-1804, 2001.

Müller, J.-F. and Stavrakou, T.: Inversion of $\mathrm{CO}$ and $\mathrm{NO}_{\mathrm{x}}$ emissions using the adjoint of the IMAGES model, Atmos. Chem. Phys., 5, 1157-1186, doi:10.5194/acp-5-1157-2005, 2005.

Napelenok, S., Cohan, D., Hu, Y., and Russell, A.: Decoupled direct 3D sensitivity analysis for particulate matter (DDM-3D/PM), Atmos. Environ., 40, 6112-6121, 2006.

Nenes, A., Pandis, S., and Pilinis, C.: ISORROPIA: A New Thermodynamic Equilibrium Model for Multiphase Multicomponent Inorganic Aerosols, Aquat. Geochem., 4, 123-152, 1998.

Nenes, A., Pandis, S., and Pilinis, C.: Continued development and testing of a new thermodynamic aerosol module for urban and regional air quality models, Atmos. Environ., 33, 1553-1560, 1999.

Neuman, J., Nowak, J., Brock, C., Trainer, M., Fehsenfeld, F., Holloway, J., Hübler, G., Hudson, P., Murphy, D., Nicks Jr, D., Orsini, D., Parrish, D., Ryerson, T., Sueper, D., Sullivan, A., 
and Weber, R.: Variability in ammonium nitrate formation and nitric acid depletion with altitude and location over California, J. Geophys. Res., 108, 4557-4569, 2003.

Nowak, J., Huey, L., Russell, A., Tian, D., Neuman, J., Orsini, D., Sjostedt, S., Sullivan, A., Tanner, D., Weber, R., Nenes, A., Edgerton, E., and Fehsenfeld, F.: Analysis of urban gas phase ammonia measurements from the 2002 Atlanta Aerosol Nucleation and Real-Time Characterization Experiment (ANARChE), J. Geophys. Res., 111, D17308, doi:10.1029/2006JD007113, 2006.

Orsini, D., Ma, Y., Sullivan, A., Sierau, B., Baumann, K., and Weber, R.: Refinements to the particle-into-liquid sampler (PILS) for ground and airborne measurements of water soluble aerosol composition, Atmos. Environ., 37, 1243-1259, 2003.

Park, R. J., Jacob, D., Field, B., Yantosca, R., and Chin, M.: Natural and transboundary pollution influences on sulfate-nitrateammonium aerosols in the United States: Implications for policy, J. Geophys. Res., 109, D15204, doi:10.1029/2003JD004473, 2004.

Pilinis, C., Capaldo, K., Nenes, A., and Pandis, S.: MADM-A new multicomponent aerosol dynamics model, Aerosol Sci. Tech., 32, 482-502, 2000.

Pinder, R. W., Adams, P. J., and Pandis, S. N.: Ammonia Emission Controls as a Cost-Effective Strategy for Reducing Atmospheric Particulate Matter in the Eastern United States, Environ. Sci. Technol., 41, 380-386, 2007.

Pye, H., Liao, H., Wu, S., Mickley, L., Jacob, D., Henze, D., and Seinfeld, J.: Effect of changes in climate and emissions on future sulfate-nitrate-ammonium aerosol levels in the United States, J. Geophys. Res., 114, D01205, doi:10.1029/2008JD010701, 2009.

Resler, J., Eben, K., Jurus, P., and Liczki, J.: Inverse modeling of emissions and their time profiles, Atmos. Poll. Res., 1, 288-295, 2010.

Rodgers, C.: Inverse Methods for Atmospheric Sounding, Theory and Practice, World Scientific, Singapore, 2000.

Sandu, A., Daescu, D., Carmichael, G., and Chai, T.: Adjoint sensitivity analysis of regional air quality models, J. Comput. Phys., 204, 222-252, 2005a.

Sandu, A., Liao, W., Carmichael, G., Henze, D., and Seinfeld, J.: Inverse Modeling of Aerosol Dynamics Using Adjoints: Theoretical and Numerical Considerations, Aerosol Sci. Tech., 39, 677-694, 2005b.

Sasaki, Y.: An objective analysis based on the variational method., J. Meteorol. Soc. Jpn., 36, 77-88, 1958.

Saxena, P., Belle Hudischewskyj, A., Seigneur, C., and Seinfeld, J.: A comparative study of equilibrium approaches to the chemical characterization of secondary aerosols, Atmos. Environ., 20, 1471-1483, 1986.

Schaap, M., Timmermans, R. M. A., Roemer, M., Boersen, G. A. C., Builtjes, P. J. H., Sauter, F. J., Velders, G. J. M., and Beck, J. P.: The LOTOS-EUROS model: description, validation and latest developments, Int. J. Environ. Pollut., 32, 270-290, 2008.

Schmidt, H., Derognat, C., Vautard, R., and Beekmann, M.: A comparison of simulated and observed ozone mixing ratios for the summer of 1998 in Western Europe, Atmos. Environ., 35, 62776297, 2001.

Seinfeld, J. H. and Pandis, S. N.: Atmospheric Chemistry and Physics: From Air Pollution to Climate Change, John Wiley, New York, USA, 2nd edn., 2006.
Seinfeld, J. H., Carmichael, G. R., Arimoto, R., Conant, W. C., Brechtel, F. J., Bates, T. S., Cahill, T. A., Clarke, A. D., Doherty, S. J., Flatau, P. J., Huebert, B. J., Kim, J., Markowicz, K. M., Quinn, P. K., Russell, L. M., Russell, P. B., Shimizu, A., Shinozuka, Y., Song, C. H., Tang, Y., Uno, I., Vogelmann, A. M., Weber, R. J., Woo, J.-H., and Zhang, X. Y.: ACE-ASIA: Regional Climatic and Atmospheric Chemical Effects of Asian Dust and Pollution, B. Am. Meteorol. Soc., 85, 367-380, 2004.

Sekiyama, T. T., Tanaka, T. Y., Shimizu, A., and Miyoshi, T.: Data assimilation of CALIPSO aerosol observations, Atmos. Chem. Phys., 10, 39-49, doi:10.5194/acp-10-39-2010, 2010.

Shindell, D., Lamarque, J.-F., Unger, N., Koch, D., Faluvegi, G., Bauer, S., Ammann, M., Cofala, J., and Teich, H.: Climate forcing and air quality change due to regional emissions reductions by economic sector, Atmos. Chem. Phys., 8, 7101-7113, doi:10.5194/acp-8-7101-2008, 2008.

Shindell, D. T., Faluvegi, G., Koch, D. M., Schmidt, G. A., Unger, N., and Bauer, S. E.: Improved Attribution of Climate Forcing to Emissions, Science, 326, 716-718, 2009.

Solomon, P. A., Chameides, W., Weber, R., Middlebrook, A., Kiang, C. S., Russell, A. G., Butler, A., Turpin, B., Mikel, D., Scheffe, R., Cowling, E., Edgerton, E., St John, J., Jansen, J., McMurry, P., Hering, S., and Bahadori, T.: Overview of the 1999 Atlanta Supersite Project, J. Geophys. Res., 108, 8413-8437, doi:10.1029/2001JD001458, 2003.

Squire, W. and Trapp, G.: Using complex variables to estimate derivatives of real functions, SIAM Rev., 40, 110-112, 1998.

Streets, D. G., Zhang, Q., Wang, L., He, K., Hao, J., Wu, Y., Tang, Y., and Carmichael, G. R.: Revisiting China's CO emissions after the Transport and Chemical Evolution over the Pacific (TRACE-P) mission: Synthesis of inventories, atmospheric modeling, and observations, J. Geophys. Res., 111, D14306, doi:10.1029/2006JD007118, 2006.

Talagrand, O.: On the mathematics of data assimilation, Tellus, 33(4), 321-339, 1981.

Talagrand, O. and Courtier, P.: Variational assimilation of meteorological observations with the adjoint vorticity equation. 1 . Theory, Q. J. Roy. Meteorol. Soc., 113, 1311-1328, 1987.

Uno, I., Yumimoto, K., Shimizu, A., Hara, Y., Sugimoto, N., Wang, Z., Liu, Z., and Winker, D. M.: 3D structure of Asian dust transport revealed by CALIPSO lidar and a 4DVAR dust model, Geophys. Res. Lett., 35, L06803, doi:10.1029/2007GL032329, 2008.

US EPA: Air Quality Criteria for Particulate Matter, National Center for Environmental Assessment - RTP Office, Office of Research and Development, EPA/600/P-99/002aF, 2004.

Vayenas, D., Takahama, S., Davidson, C., and Pandis, S.: Simulation of the thermodynamics and removal processes in the sulfate-ammonia-nitric acid system during winter: Implications for $\mathrm{PM}_{2.5}$ control strategies, J. Geophys. Res., 110, D07S14, doi:10.1029/2004JD005038, 2005.

Vogel, B., Vogel, H., Bäumer, D., Bangert, M., Lundgren, K., Rinke, R., and Stanelle, T.: The comprehensive model system COSMO-ART- Radiative impact of aerosol on the state of the atmosphere on the regional scale, Atmos. Chem. Phys., 9, 86618680, doi:10.5194/acp-9-8661-2009, 2009.

Vukićević, T. and Hess, P.: Analysis of tropospheric transport in the Pacific Basin using the adjoint technique, J. Geophys. Res., 105, 7213-7230, 2000.

West, J., Pilinis, C., Nenes, A., and Pandis, S.: Marginal direct 
climate forcing by atmospheric aerosols, Atmos. Environ., 32, 2531-2542, 1998.

West, J., Ansari, A., and Pandis, S.: Marginal $\mathrm{PM}_{2.5}$ : Nonlinear aerosol mass response to sulfate reductions in the Eastern United States, J. Air Waste Manag. Assoc., 49, 1415-1424, 1999.

Yumimoto, K., Uno, I., Sugimoto, N., Shimizu, A., and Satake, S.: Adjoint inverse modeling of dust emission and transport over East Asia, Geophys. Res. Lett., 34, L08806, doi:10.1029/2006GL028551, 2007.

Yumimoto, K., Uno, I., Sugimoto, N., Shimizu, A., Liu, Z., and Winker, D. M.: Adjoint inversion modeling of Asian dust emission using lidar observations, Atmos. Chem. Phys., 8, 28692884, doi:10.5194/acp-8-2869-2008, 2008.
Zaveri, R., Easter, R., and Peters, L.: A computationally efficient multicomponent equilibrium solver for aerosols (MESA), J. Geophys. Res., 110, D24203, doi:10.1029/2004JD005618, 2005.

Zhang, L., Constantinescu, E., Sandu, A., Tang, Y., Chai, T., Carmichael, G., Byun, D., and Olaguer, E.: An adjoint sensitivity analysis and 4D-Var data assimilation study of Texas air quality, Atmos. Environ., 42, 5787-5804, 2008.

Zhang, W., Capps, S. L., Hu, Y., Nenes, A., Napelenok, S. L., and Russell, A. G.: Development of the high-order decoupled direct method in three dimensions for particulate matter: enabling advanced sensitivity analysis in air quality models, Geosci. Model Dev. Discuss., 4, 2605-2633, doi:10.5194/gmdd-4-2605-2011, 2011. 